Article

\title{
Anticlerical Motifs in the Illustrations of Martin Luther's Hauspostille
}

\author{
Grażyna Jurkowlaniec ${ }^{1, *(1)}$ and Maciej Ptaszyński ${ }^{2}$ (D) \\ 1 Institute of Art History, University of Warsaw, Krakowskie Przedmieście 26/28, 00-927 Warszawa, Poland \\ 2 Faculty of History, University of Warsaw, Krakowskie Przedmieście 26/28, 00-927 Warszawa, Poland; \\ m.ptaszynski@uw.edu.pl \\ * Correspondence: g.jurkowlaniec@uw.edu.pl
}

Received: 31 October 2020; Accepted: 19 November 2020; Published: 25 November 2020

\begin{abstract}
Drawing on the example of the editions of a Protestant bestseller, Martin Luther's Hauspostille, printed several times in Nuremberg between 1544 and 1548 by Johann vom Berg and Ulrich Neuber, the study examines the sources, location, and function of the anticlerical motifs in the Protestant postils. Prominent in the first editions of the Hauspostille of 1544 and 1545, the anticlerical scenes were eliminated in 1548. The authors argue that both the usage and subsequent removal of these woodcuts was dependent not on the direct religious context in Luther's sermons, but on pragmatic political considerations as they affected the religious situation in the city of Nuremberg. The deployment of antipapal imagery in the mid-1540s coincided with Nuremberg's strong engagement in the aggravating conflict between the emperor and the Protestants, whereas its elimination was triggered by the defeat of Protestants and the introduction of the Augsburg Interim.
\end{abstract}

Keywords: Reformation; anticlericalism; postil; woodcut; Martin Luther; Hauspostille; Nuremberg; Augsburg Interim

\section{Introduction: The Disappearing Demon and Anticlerical Threads in the First Decades of the Reformation}

Among numerous books published by Johann vom Berg and Ulrich Neuber in Lutheran Nuremberg in the mid-sixteenth century, a woodcut recurs, modest in its artistic value, but interesting with respect to iconography. In the foreground, there is a scene of communion, while in the background is a procession led by the priest carrying the Blessed Sacrament in the monstrance (Figure 1a). Two motifs convince us that the scene juxtaposes two approaches to the sacrament of the Eucharist: the Dove of the Holy Spirit hovers above the altar where communion is given, while a black winged dragon flies above the procession. Thus, the scene compares and contrasts the true Christian religion and the papal superstition.

This woodcut first accompanied Martin Luther's sermon on the sacrament of the Eucharist included in the first edition of his Hauspostille of 1544 (Luther 1544a, fol. CCXXXVII; Luther 1544b, fol. LXXXIVv). In subsequent years, consistent with the common practice, vom Berg and Neuber kept reusing the block, which underwent a slight yet significant correction: in 1548, the printers eliminated the figure of the dragon over the procession (Luther 1548, fol. CVI) (Figure 1b). As a result, if it were not for the fact that the scene continued to illustrate Luther's Hauspostille, as well as various collections of other Lutheran authors printed by vom Berg and Neuber, it could be considered an affirmation of commonality with Catholic rituals for the faithful, who kneel down to receive communion under one kind and devoutly participate in the Corpus Christi procession. Therefore, both the presence and the subsequent elimination of the dragon - a motif that sets the scene's main message - in the woodcut illustrating Lutheran prints produced in Nuremberg of the mid-sixteenth century require clarification. 


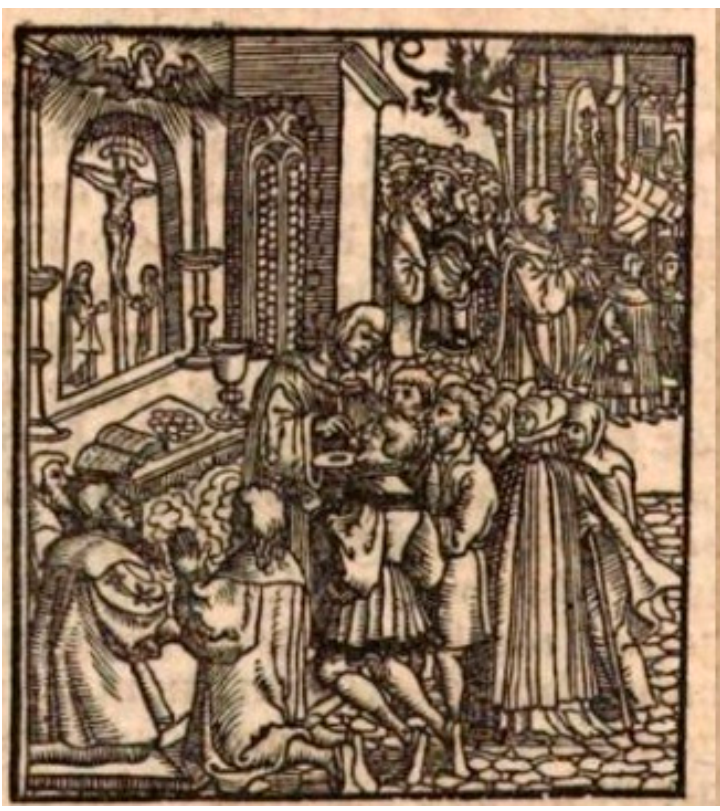

(a)

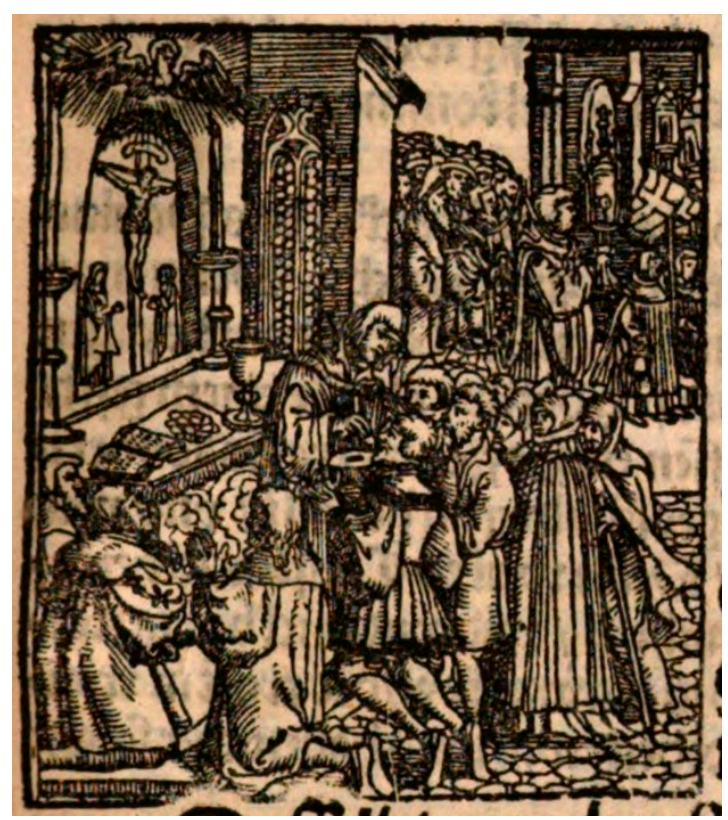

(b)

Figure 1. Communion and procession, woodcut recurring in books published by vom Berg and Neuber [S 22] (see Appendix A) (a) in (Luther 1544b, fol. LXXXIVv) (Munich, Bayerische Staatsbibliothek, 2 Hom. 277, urn:nbn:de:bvb:12-bsb10144039-2; NoC-NC/1.0) (b) in (Luther 1548, fol. CVI) (Munich, Bayerische Staatsbibliothek, 2 Hom. 281, urn:nbn:de:bvb:12-bsb10144040-5; NoC-NC/1.0).

Anticlerical motifs were prominent in the literary and visual culture at the dawn of the Reformation. Luther himself, still an Augustinian friar, resorted to the late medieval arsenal of criticism of the clergy-especially monks - in the 1520 To the Christian Nobility of the German Nation. In this treatise, which soon became a bestseller of the Reformation era, Luther attacked the Pope, the monks, and celibate priests, but above all-in response to his ongoing trial in Rome and in anticipation of the inevitable sentence-he turned to the laity, rulers, and nobles, entrusting them with the reform of the Church, as well as challenging the distinction between the clergy and laity (Luther [1520] 1520; Moeller 1993; Kaufmann 2014). Harsh criticism of the Pope, the Roman Curia and the Church's hierarchy, which takes up late medieval, mostly Hussite, and Renaissance sources, such as Lorenzo Valla's writings, become a permanent feature of all confessional polemics in the years to come (Whitford 2008; Buck 2011; Buck 2014; Haberkern 2016).

Omnipresent in popular pamphlets, anticlericalism did not find its way as quickly into the religious literature that had flourished since the mid-fifteenth century. After a short period of production collapse or "saturation of the market" in the years preceding the Reformation (cf. Burkhardt 2002), the collections of sermons became bestsellers in the emerging book market (Frymire 2010, p. 184; Milway 2000). Luther, who aptly recognized the faithful's expectations and market demand, was already preparing his first collections of sermons during his stay in Wartburg in 1521. The 1520s and 1530s witnessed a number of versions of postils published under Luther's name, mostly completed and edited by his collaborators or former students, such as Stephan Roth, Caspar Cruciger, or Veit Dietrich. While the two former contributed to completing the Kirchenpostille, the latter edited the Hauspostille, first printed in Nuremberg in 1544 by Johann vom Berg and Ulrich Neuber. Soon, Luther was joined by a host of Protestant theologians who penned their own collections of sermons (Rublack 1992), and the Catholic authors also reached for the genre, "meeting Luther on his own terms" (Frymire 2010, p. 50).

Publication of Luther's postils was in various ways related with the current political events: the period of the German Peasants' War of 1525, the first official Church visitation in Saxony of 1527-1528, the rise and fall of the Anabaptist Kingdom of Münster in 1534 (Frymire 2010, pp. 36, 77). The authors or publishers frequently explicitly elaborated on their motivations in the postils' prefaces, often addressed 
to the territorial rulers. The prefaces presented the postil as both a convenient aid for pastors and a tool to control the teachings preached in churches; they reveal the introduction of the Reformation as being increasingly dependent on the support of secular sovereignty. At the same time, collections of model sermons became an integral part of building the Lutheran Landeskirchen and in various Protestant territories orders were issued to purchase postils in addition to the Bible, Church ordinances, agendas and Luther's works (Karant-Nunn 1979; Frymire 2010, pp. 113, 123; Ptaszyński 2017, p. 347). Anticlericalism was difficult to reconcile with these intentions and the context in which the postils were disseminated, although motifs directed against the papal Church were present in several sermons.

The woodcut discussed at the outset invites us to consider the role of visual imagery in this context. The very phenomenon of the introduction and subsequent elimination of anti-Pope threads from illustrations of Protestant prints has been widely described in the scholarly literature. However, it is usually associated with the motif of the papal tiara appearing and disappearing from the heads of the Whore of Babylon and the Beast in the apocalyptic cycle of the Bible (Chojecka 1961; Martin 1983; De Hommel-Steenbakkers 2009; Jurkowlaniec 2017), whereas the illustrations of postils remain almost unexplored. Yet the first editions of the Hauspostille printed by vom Berg and Neuber include not only the above-mentioned communion and procession scene, but also several other woodcuts with unquestionably anti-Catholic overtones. Illustrations of early modern sermons are generally very poorly researched (cf. Komorowska 2015). Therefore, before specific cycles used by vom Berg and Neuber are examined, it is necessary to at least briefly characterize a typical series of postil illustrations and to distinguish specific contexts where polemic threads occasionally appeared.

\section{Cycles in Early Modern Postils}

When trying to outline a typical scheme of postil illustrations, two approaches should be adopted: the one focuses on iconography, the other on the practicalities of book production. In terms of iconography, each element of the cycle represents a scene that has to be analysed with respect to its particular features, pictorial sources, and correspondence with the text it accompanies, but above all in relation to other illustrations in the same publication. Each postil illustration usually refers to the respective Gospel pericope or, as in the case of saints, to the person commemorated in the given feast (Appendix A). Therefore, the selection of scenes covers the most important events in the life of Christ, as well as also the parables, exhortations, or warnings he preached to the disciples or the Pharisees. Comprehensive Christological cycles can be traced back to the Early Middle Ages, the Greek Rossano Gospels (Rossano, Diocesan Museum) and Sinope Gospels (Paris, Bibliothèque nationale de France, MS suppl. gr. 1286), or the Latin St. Augustine Gospels (Cambridge, Corpus Christi College, MS 286), to mention several. As early as the twelfth century, such cycles occasionally included more than 100 or even about 150 scenes, as is the case of Eadwin's Psalter (Cambridge, Trinity College, MS R. 17.1).

In many early modern printed bibles, especially Protestant ones, the historical books of the Old Testament and the Apocalypse have a rich figural decoration, whereas the Gospels often remain unillustrated. The bibles published by vom Berg and Neuber are no exception, with the Gospels preceded by full-page images of the Evangelists, but otherwise not illustrated (Biblia 1550, 1554). Nonetheless, renowned artists of the mid-sixteenth century-Hans Brosamer, Virgil Solis, and Jost Amman-designed collections of New Testament scenes, published separately (Novi testamenti historia 1551; Biblische Figuren 1560; Neue biblische Figuren 1565), but also serving as bible illustrations (Chojecka 1961). In all of these scenes are arranged in chronological order the life and teaching of Christ, whereas in the postils the choice and order of the scenes are strictly subordinated to the liturgical year. Thus, if the first scene of a typical Christological cycle is the Annunciation or Nativity, in the postil it is the Entrance to Jerusalem, consistent with the pericope for the First Sunday of Advent.

In highly conventionalized publications, which postils are, one may easily note various kinds of repetitiveness. Typically, scenes that are identical as to subject and often alike as to design keep recurring in the same contexts. However, in contrast to illuminated manuscripts in which each illustration has to 
be painted individually, the figures in printed books are impressed from matrices. Therefore, one has to consider the perspective that focuses on the practical conditions of book production. It involves such questions as: How many blocks were at the printer's disposal? How consistently were certain designs placed in established contexts? To what extent were the matrices used in coherent sets and in which circumstances were defined sets combined or completed with individual scenes?

The rhythm of the liturgical year allows for the definition of the framework of the cycle, and thus, at least to some extent, determines the stock of matrices that should be at a printer's disposal to illustrate each Sunday and feast. A complete postil consists of three parts: winter postil (Sundays of Advent through to the end of Lent), summer postil (Sundays of Easter through to the end of the church year), and festival postil (feasts of Christ, Mary and saints). If each entry were to be accompanied by a unique scene, 52 original designs would be indispensable for Sundays alone, to which one must add illustrations for Good Friday and the Mondays and even Tuesdays of the most important feasts such as Easter or Pentecost, and an indefinite number of scenes referring to various days or ceremonies included in the festival postil. Finally, many winter postils were supplemented with a series of Passion sermons that were often illustrated too.

A full cycle might, therefore, cover far more than 100 scenes, which does not mean, however, that as many matrices are required. Admittedly, the number of pericopes is larger than the number of Sundays and holidays, as the most important feasts have sometimes been accorded several readings, but the illustration usually accompanies only the first of these. Some pericopes-drawn from different books of the Bible and read on different days-are similar in content, so they do not necessarily require separate compositions, as is the case with several stories included in the synoptic Gospels. Sometimes the pericope contains only a fragment of a story, whose other fragment is read on another day. An example is the Presentation of Christ, recalled two or three times during the liturgical year. On the Sunday after Christmas, the verses are read out with the prophecy of Simeon announcing the sword of sorrow that will penetrate Mary's heart (Lk 2: 33-40). On the feast of the Presentation of the Lord, celebrated on 2 February, the events preceding Simeon's prophecy are recalled: the arrival of the Holy Family at the temple and the offering of a pair of turtle doves (Lk 2: 22-24). This passage, included in the winter postil, occasionally recurs in the festival postil, because the Presentation of the Lord is also celebrated as a Marian feast: the Purification of the Virgin. Therefore, in many three-part postils various fragments of Luke's story can be found in three places, usually illustrated with an identical woodcut. Moreover, several readings, especially in the summer postil, do not refer to narrative events, but recall various of Christ's exhortations or admonitions. Usually Christ's instructions and parables were depicted as separate scenes, but occasionally just one composition, showing Christ among the disciples, was repeated in all such contexts (e.g., Teutsch Ewangeli 1516).

In practice, sets of about 80 matrices were used to illustrate most of the three-part postils, even those that included Passion sermons. A very popular cycle, developed for Luther's Kirchenpostille, used several times by Hans Lufft and Georg Rhau in Wittenberg from around 1530, consisted of 84 blocks (Luther 1530). Another widely disseminated cycle, designed by Hans Brosamer in the late 1520s and first used by Michael Lotter in Magdeburg, included 80 items (Luther 1529; cf. Knauer 2015). However, another successful cycle designed by Brosamer a dozen years later and first used by Nicolaus Wolrab in Leipzig in 1544 (Luther 1544c) has only 64 scenes, because it only encompasses the scenes for the winter and summer postils. In such cases, the printers usually reimpressed some of these in the festival postil, and, thus, for instance, the Incredulity of St Thomas, typically accompanying the First Sunday after Easter, might also recur on the Feast of St Thomas the Apostle, when the pericope is almost identical. However, there were other cases: e.g., the story of the sinner that anointed Christ's feet (Lk 7: 36-50) is only read on St Mary Magdalen's Day. Since Brosamer's 1544 series did not include a respective scene, the printer might either forego the illustration or complement the principal cycle with an illustration from another set. Indeed, using more than one set of matrices to illustrate a single publication was a widespread practice that may also be observed in vom Berg and Neuber's printing shop in Nuremberg, notably in their editions of Luther's Hauspostille (Appendix A). 
Many printers had more than one set of blocks similar as to iconography, but different as to size, which is not accidentally consistent with the fact that postils were also printed in various formats, most typically either in folio or in octavo. Obviously, in the latter format only small woodcuts could have been used. There was more room for manoeuvre in the folio size; therefore, such editions are a particularly fruitful point of departure for an investigation into the criteria of selecting not only iconographic subjects, but also particular designs. This brings us to the crucial question as to whether the postil illustrations follow the respective pericopes only or, at least occasionally, refer to the content of the sermon in a given collection or, perhaps, reflect particular historical circumstances of its publication. Usually, the repeatability of the Gospel narratives, shared by Lutherans and Catholics, does not encourage the introduction of controversial motifs. However, there are remarkable exceptions.

In the editions of Luther's Kirchenpostille printed by Lufft and Rhau in Wittenberg from 1529, the illustration for the Eighth Sunday after Trinity has clearly antipapal overtones. The pericope (Mt 7: 15-20) starts with a warning against false prophets who are wolves in sheep's clothing, and further develops the comparison between a fruit-bearing and a fruitless tree. The woodcut depicts a group of disciples around Christ pointing at animals with curly fur on their backs (Figure 2). The quadrupeds are crowded by the tree on whose trunk an indulgence letter hangs, and their true identity is betrayed by their headgear: the biretta, the galero, and the papal tiara. Equally sneaky and even more bloodthirsty are the wolves carrying sheep in their mouths, as shown in a woodcut with a very similar composition (in mirror image) in Luther's postils printed by Hans Weiss (Luther 1532).

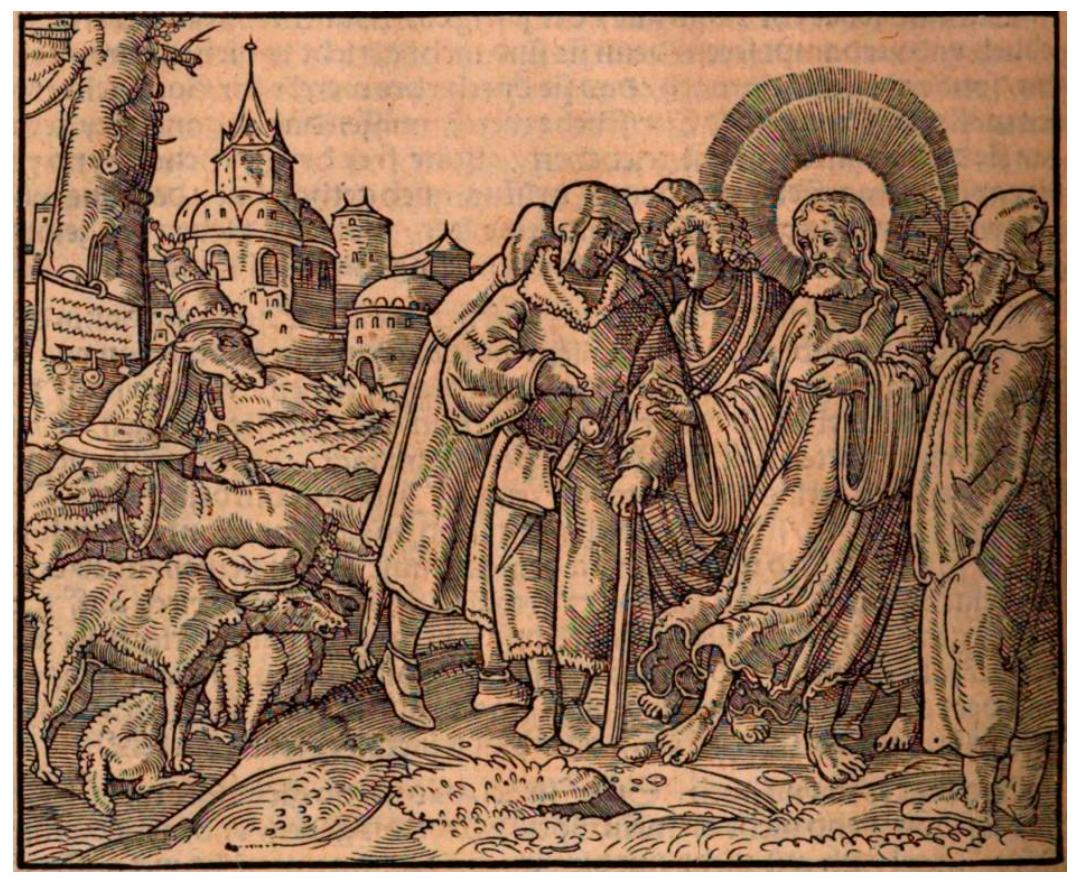

Figure 2. Warning against false prophets, ca. 1529, in (Luther 1530), part 2, fol. [C]LXIIv (Augsburg, Staats- und Stadtbibliothek, 2 Th Pr 144\# (Beibd. 1, urn:nbn:de:bvb:12-bsb11204848-8; NoC-NC/1.0).

By contrast, the scenes for the Eighth Sunday after Trinity in two cycles designed by Hans Brosamer in the late 1520s and in the 1540s, respectively (?, [H 955nd [H 1047]]B70-religions-1003049), focus on comparing two trees and do not contain anticlerical accents (Figure 3). Nevertheless, other scenes in Brosamer's cycles, the Parable of the sheepfold, feature a robber with monk habit and tonsure breaking into the building (?, [H 945nd [H 1038]]B70-religions-1003049) (Figure 4). One has to note, however, that the Parable of the sheepfold illustrates the pericope for the Tuesday after Pentecost, a day included in Luther's Kirchenpostille, but unacknowledged in the Hauspostille and most other collections of sermons. Nonetheless, the Hauspostille's first Nuremberg editions are exceptional in terms of both the number and sharpness of anticlerical motifs. 


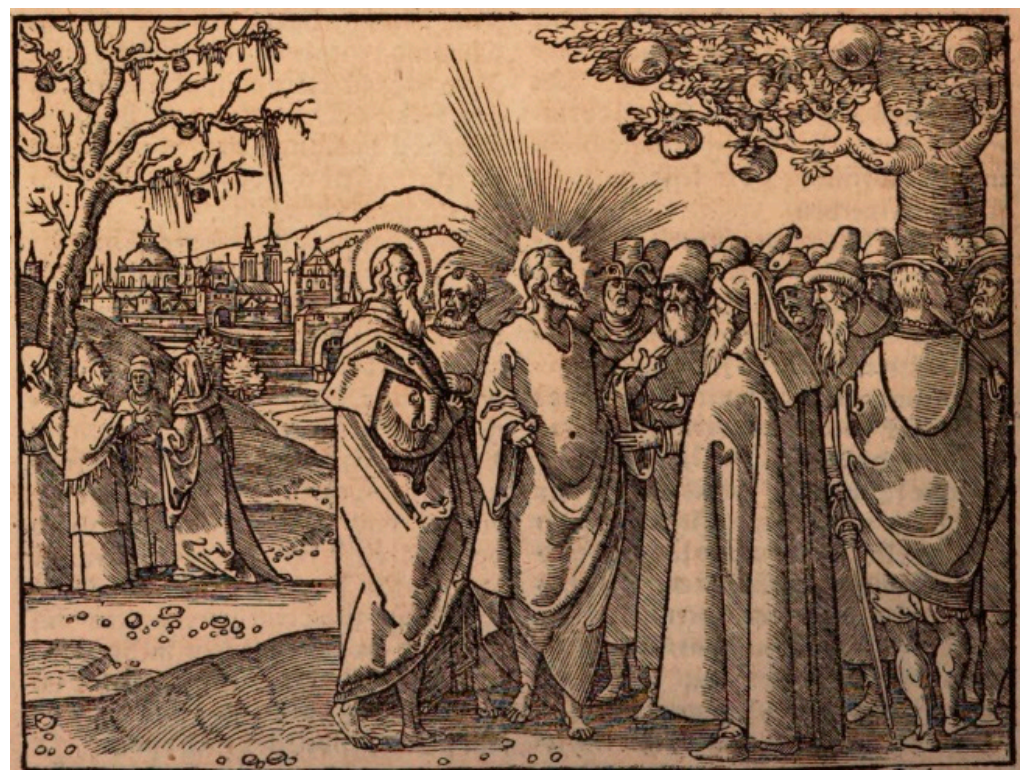

Figure 3. Hans Brosamer, Warning against false prophets [H 1047], ca. 1544, in (Luther 1544c) part 2, fol. CCXXIXv (Munich, Bayerische Staatsbibliothek, 2 Hom. 306-3, urn:nbn:de:bvb:12-bsb-10 144065-2; NoC-NC/1.0).

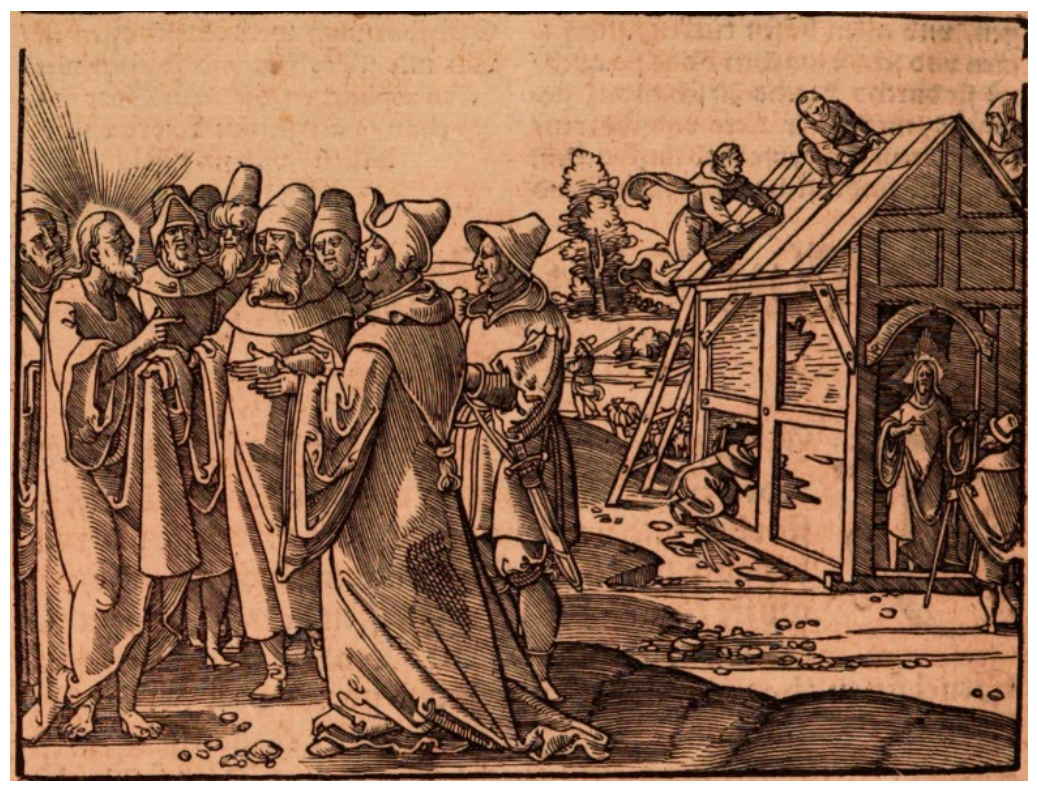

Figure 4. Hans Brosamer, Parable of the sheepfold [H 1038], ca. 1544, in (Luther 1544c) part 2, fol. CXXXv (Munich, Bayerische Staatsbibliothek, 2 Hom. 306-3, urn:nbn:de:bvb:12-bsb-10 144065-2; NoC-NC/1.0).

\section{Vom Berg and Neuber's Two Sets of Matrices}

\subsection{Square Blocks First Used in 1544}

In the 1540s and 1550s, vom Berg and Neuber used a few sets of matrices to illustrate various collections of sermons for Sundays and holidays of the liturgical year (Appendix A). The woodcut discussed in the introduction is part of the oldest set, comprising 72 almost square blocks $(60 \times 68 \mathrm{~mm})$, first used in the 1544 editions of the Hauspostille, printed in folio and in octavo (Luther 1544a, 1544b, cf. Luther 1544, pp. XXIX-XXX). This set was fairly adequate for the pericopes of winter, summer, and festival postils, even if it lacked some individual scenes, such as Circumcision and Ascension that 
were impressed from much older blocks $(63 \times 50 \mathrm{~mm})$ used in Nuremberg since the early sixteenth century (Dodgson 1909; Schoch Rainer and Scherbaum 2004, pp. 512-13, n. A38). The 1544 set did not include the Passion cycle either, but it was completed with two different Crucifixions, one of which is a simplified copy of Lucas Cranach's woodcut of 1509 (Dodgson 1911).

The 1544 cycle comprises several scenes with peculiar iconography. For instance, the feast of the Holy Trinity is not accompanied by a scene of Christ's conversation with Nicodemus, usual in this context, but by an illustration that combines three topics, each referring to respective Persons of the Trinity: God the Father creating Adam, the crucified Christ, and the Holy Spirit at the Pentecost (Figure 5a). Another unusual woodcut depicts a scene that may be labelled as Two Kingdoms, referring to Luther's "two kingdoms doctrine" (Zwei-Reiche-Lehre) (Figure 5b).

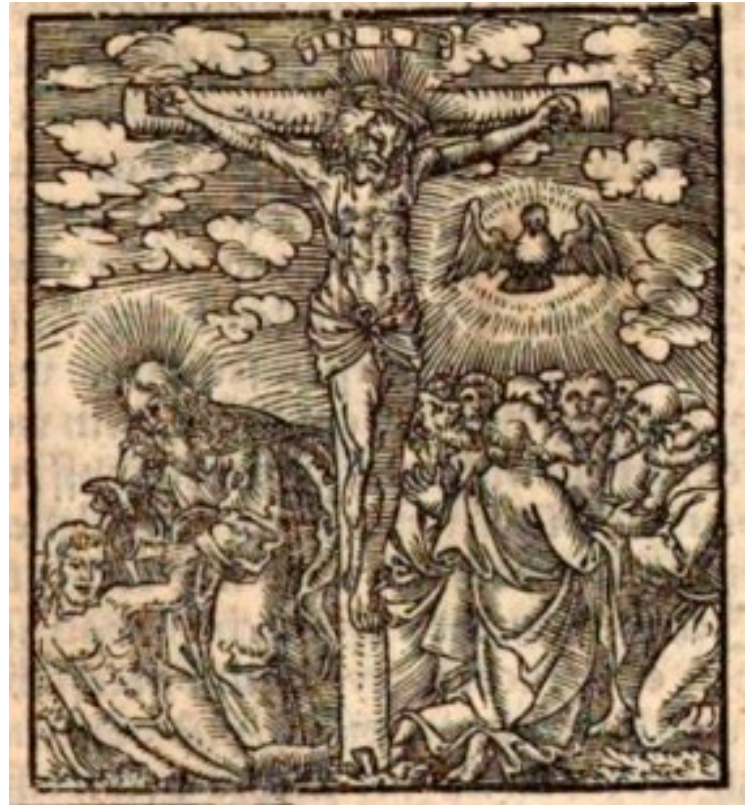

(a)

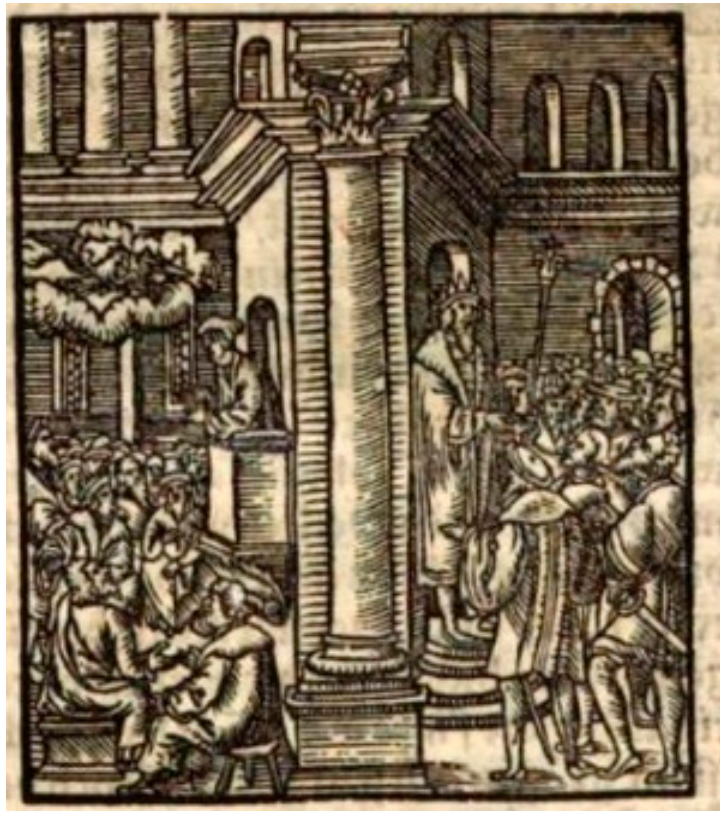

(b)

Figure 5. Woodcuts recurring in books published by vom Berg and Neuber. (a) Holy Trinity (Creation of Adam, Crucifix, and Pentecost) [S 32], in (Luther 1544b, fol. CXLIV) (Munich, Bayerische Staatsbibliothek, 2 Hom. 277, urn:nbn:de:bvb:12-bsb10144039-2; NoC-NC/1.0); (b) Two Kingdoms [S 69], in (Luther 1544b, part 3, fol. LXII) (Munich, Bayerische Staatsbibliothek, 2 Hom. 277, urn:nbn:de:bvb:12-bsb10144039-2; NoC-NC/1.0).

Above all, however, this cycle is distinguished by the number of anti-Catholic motifs. The scene discussed in the introduction, included in the winter postil, refers to Palm Sunday (Luther 1544, pp. 205-16). The starting point of Luther's sermon for this day is not the Gospel but, exceptionally, an Epistle, namely the fragment of the First Letter to the Corinthians that focuses on the Lord's Supper (1Cor 11: 23-26). Elaborating on this topic, Luther emphasizes the taking of communion by the faithful, despite the negative attitudes, widespread in the papacy, arising out of such concerns as the fear of unworthy communion. He also posits that the papal instruction to give communion under one kind only is incompatible with the Gospel. Finally, Luther reminds his audience that the Eucharist is a sign of the forgiveness of sins and also creates a community of the faithful, which Satan seeks to destroy. Thus, the demon above the procession is certainly consistent with these statements, even if it has not been conceived as an illustration specifically referring to Luther's sermon on the Epistle for Palm Sunday.

A similar dragon-like demon can also be found in the summer part of the Hauspostille, in the context of the Eighth Sunday after Trinity (Luther 1544, pp. 419-27) (Figure 6a). As has already been mentioned, the pericope warning against the false prophets occasionally turned out a good opportunity 
to introduce unequivocally antipapal imagery. The Nuremberg woodcut represents a tree under which Christ and the apostles are standing, juxtaposed with a group of ecclesiastical hierarchs. The clerics all have long wolf snouts, and above their heads hovers a dragon. The message of the image is clear and it resonates with some elements of the sermon, although Luther considers not only "the Pope and the Bishops" but also the Anabaptists to be false prophets.

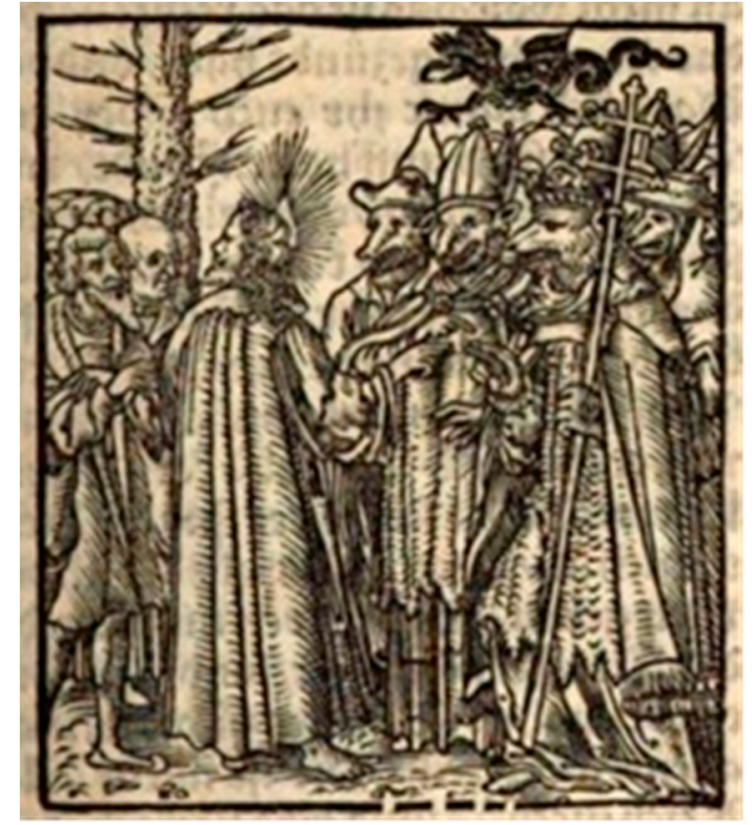

(a)

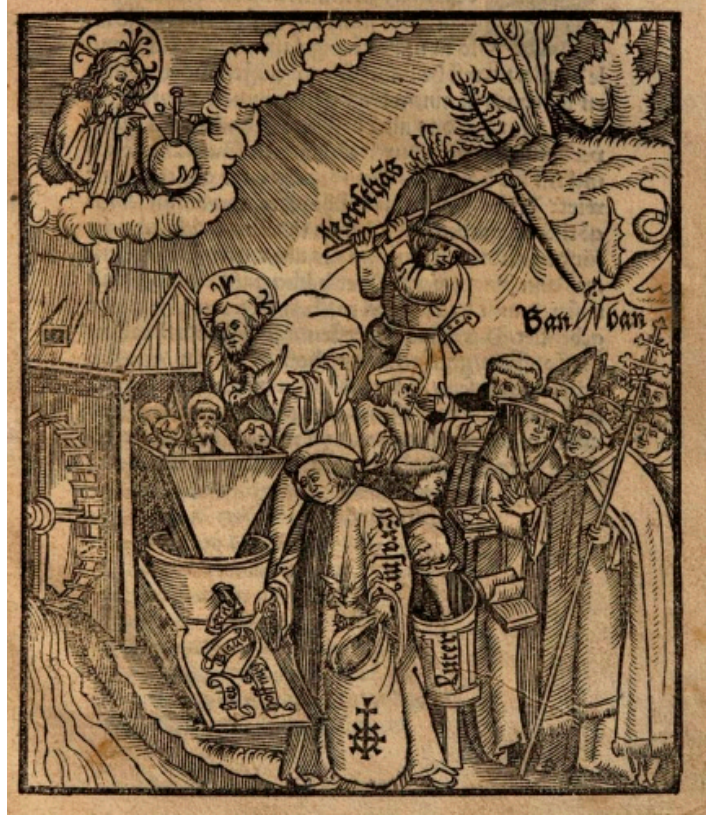

(b)

Figure 6. (a) Warning against false prophets [S 41], woodcut recurring in books published by vom Berg and Neuber, in (Luther 1544b, fol. CLXXX) (Munich, Bayerische Staatsbibliothek, 2 Hom. 277, urn:nbn:de:bvb:12-bsb10144039-2; NoC-NC/1.0); (b) The Mystical Mill, woodcut on title page of (Seeger 1521b) (Munich, Bayerische Staatsbibliothek, Res/4 P.o.germ. 226, 15 c, urn:nbn:de:bvb:12-bsb11216733-6; NoC-NC/1.0).

The polemical message of the Nuremberg composition for the Eighth Sunday after Trinity is similar to that found in the Wittenberg editions of the Kirchenpostille, but the design stems from a different iconographic tradition. Human figures with animal heads can be found in various satires of the 1520s (Scribner [1981] 1994, pp. 56-94). The motif of a dragon over a group of priests, on the other hand, evokes a fragment of a woodcut on the title page of a pamphlet of 1521, presenting a peculiar variant of the iconographic theme of the Mystical Mill (Göttler 1984; Dupuigrenet Desroussilles 2019; Leu and Weidmann 2019). First issued in Zurich (Seeger 1521a), the pamphlet was republished several times in the Reich, beginning with the Augsburg edition of 1521, with a similar illustration on the title page (Seeger 1521b) (Figure 6b) Martin Luther and Erasmus of Rotterdam play the main roles in this scene, and over a group of their opponents, the Catholic hierarchs, a dragon hovers, shouting "ban ban", which is probably an allusion to the Decet Romanum Pontificem bull excommunicating Luther (Bannbulle), published on 3 January 1521.

These two woodcuts only, the Communion and procession in the winter part and the Warning against false prophets in the summer part, would be sufficient to regard the discussed cycle as standing out among several sets of sixteenth-century postil illustrations. However, it is the festive part of the Hauspostille that proves richest in anticlerical motifs. The first example is the scene for the feast of St Stephen (Figure 7a). The woodcut depicts the moment when Stephen turns to Christ, whose bust appears in the clouds. However, it is not the Jews who stone Stephen, but Catholic monks and hierarchs. These are, again, patronized by a dragon, but this time it is holding a banderole with the inscription "HVI HVI HVI". This battle cry, quoted by Luther in a sermon preached on 10 May 
1545 (Luther [1545] 1913; Kolb 2012), seems a reminiscence of the dragon shouting "ban ban" in the Mystical Mill of 1521. The casting of Catholic clergy as torturers is in line with the sermon of the Hauspostille in which Luther elaborates on a comparison between the Jews murdering Stephen and the Papists treatment of Christians — that is, the Lutherans-in those days ("die Juden sind mit Stephano umbgangen, wie heuttigs tags die Papisten mit uns umbgehn"-Luther 1544, p. 593).

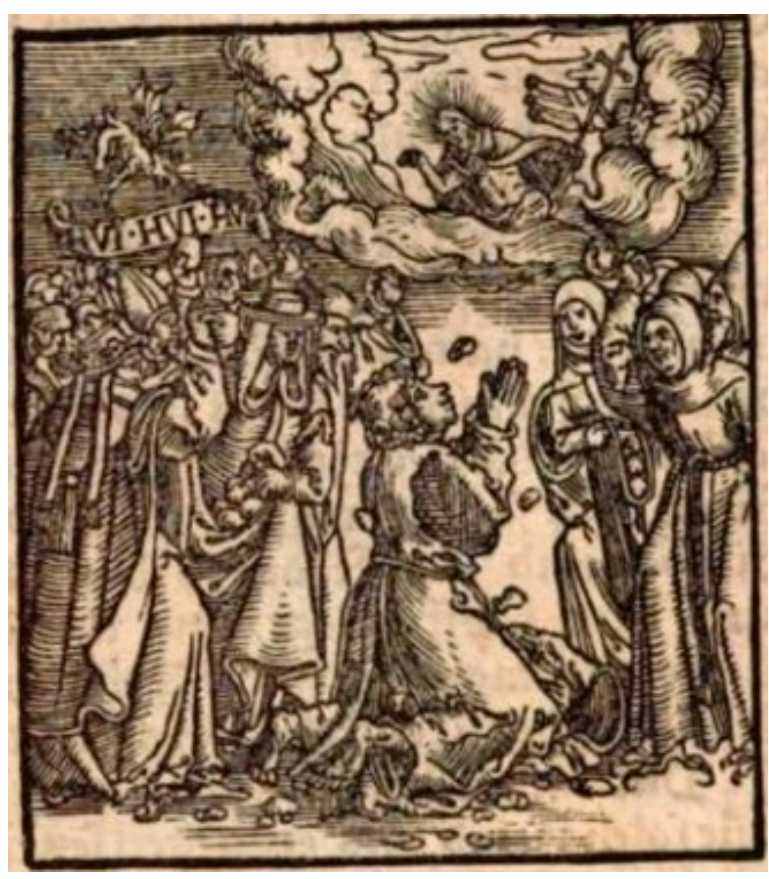

(a)

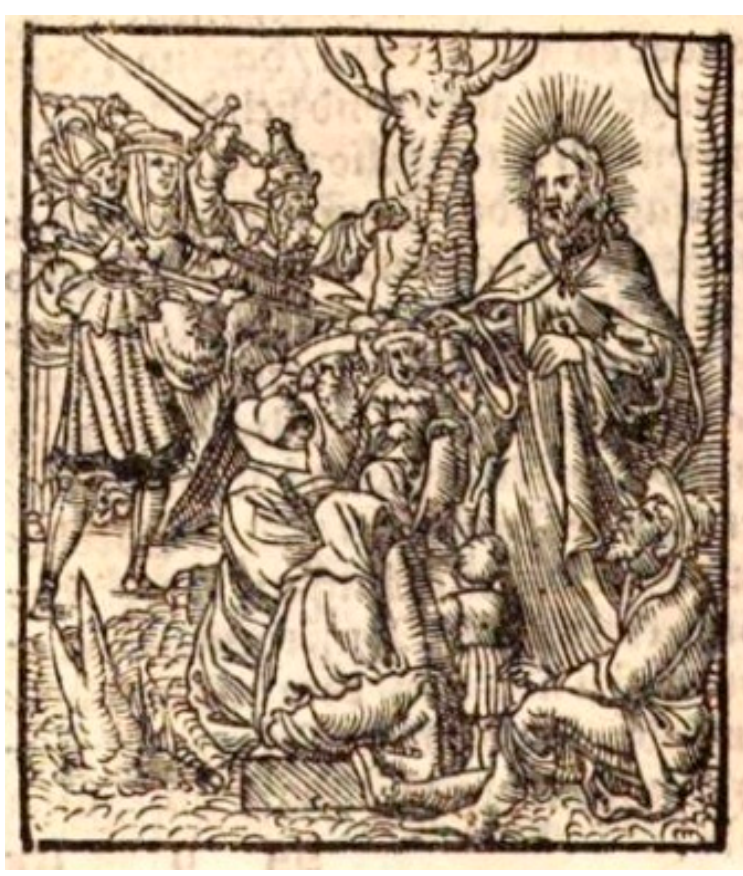

(b)

Figure 7. Woodcuts recurring in books published by vom Berg and Neuber. (a) Stoning of St Stephen [S 58], in (Luther 1544b, part 3, fol. XIIv) (Munich, Bayerische Staatsbibliothek, 2 Hom. 277, urn:nbn:de:bvb:12-bsb10144039-2; NoC-NC/1.0) (b) Christ preaching and Catholic hierarchs [S 61], in (Luther 1544b, part 3, fol. XXVIv) (Munich, Bayerische Staatsbibliothek, 2 Hom. 277, urn:nbn:de:bvb:12-bsb10144039-2; NoC-NC/1.0).

Once again, the aggression of the papists is revealed in the woodcut accompanying the feast of St Matthew (Luther 1544, pp. 617-24) (Figure 7b). It depicts in the foreground Christ teaching the faithful gathered around him, which can be directly derived from the contents of the pericope (Mt 11:25-30) that explains the doctrine revealed to the simple women, and also assures the faithful that they will find solace in Christ. This group is attacked by a troop of Catholic clergy led by the Pope with a sword. The latter motif should be associated with the passage of the sermon about the Pope, cardinals, bishops, and all priests who blaspheme and insult God's Word ("Jämmerlich und seer ergerlich ist es anzusehen, das heuttiges tages Bapst, Cardinäl, Bischoffe und andere, so de namen haben und geystlich heissen, also verächtlich das wort halten, es also lestern und schmehen"-Luther 1544, p. 619), captioned on the margin as "an example of the Papists' obstinacy" (Der Papisten verflockung ein nötiges exempel-Luther 1544b, part 3, fol. XXXII).

The feast of Saints Peter and Paul is an opportunity to recall the answers given by the apostles to the question as to who people say that the Son of Man is (Mt 16: 13-19). It was then that Simon Peter recognized in Christ the Messiah and the Son of God, where Christ called him Peter the rock and entrusted him with the keys to the Kingdom of Heaven. This time the illustration only indirectly alludes to the pericope, as the main motif is the Crucifix, over which a bust of the benedictory God the Father emerges from the clouds (Figure 8a). Thus, Christ is clearly shown as the Redeemer and Son of God, but there is no explicit reference to the dignity granted to Peter. An ecclesiological message is conveyed by the confrontation of the papacy with the true Church of Christ, as at the foot of the Cross, 
two groups of figures kneel. At the right hand of the Saviour, the faithful are gathered, on whom the blood flows from his side, with the Dove of the Holy Spirit hovering above their heads. On the other side is a group of both religious and secular hierarchs, among whom, again, a prominent role is played by the Pope. Two recurring motifs can be seen here too: the hierarchs' aggressive gestures and a sword raised against the pious believers, and a winged dragon hovering above the group. Luther's sermon includes some similar accents, accusing "the Pope and his mob" of abusing the Gospel and declaring that the Pope should not be identified with the Church (Luther 1544, pp. 654-64).

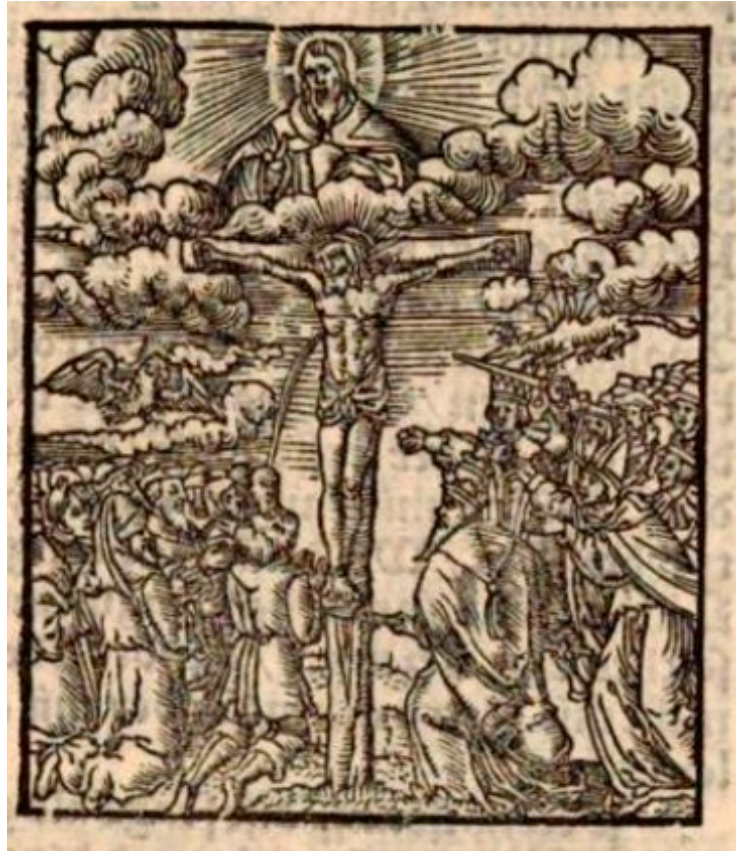

(a)

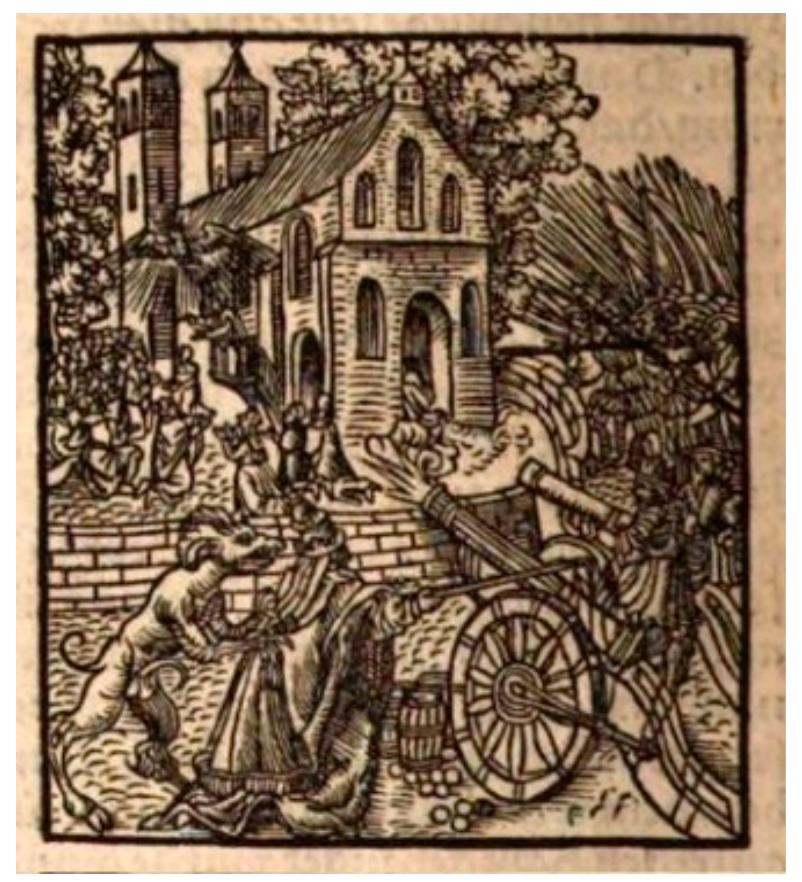

(b)

Figure 8. Woodcuts recurring in books published by vom Berg and Neuber. (a) Adoration of the Crucifix and Catholic hierarchs [S 65], in (Luther 1544b, part 3, fol. XLIII) (Munich, Bayerische Staatsbibliothek, 2 Hom. 277, urn:nbn:de:bvb:12-bsb10144039-2; NoC-NC/1.0); (b) Siege of the church [S 72], in (Luther 1544b, part 3, fol. LXXVv) (Munich, Bayerische Staatsbibliothek, 2 Hom. 277, urn:nbn:de:bvb:12-bsb10144039-2; NoC-NC/1.0).

Finally, the woodcut accompanying the pericope for the feast of Saints Simon and Jude deserves attention (Figure 8b). It shows the Pope who, in an attack instigated by the devil, personally leads the artillery fire on the church. Outside the church, a group of believers listen to the preacher, over which the Dove of the Holy Spirit hovers. The scene is initially surprising because the reading (J 15: 12-17) begins with a reminder of the commandment of love. However, then there is the announcement of persecution that will be Christ's disciples' lot. The theme of persecution is also developed by Luther in his homily, explicitly pointing out Catholic hierarchs as aggressors (Luther 1544, pp. 730-31).

\subsection{Rectangular Blocks First Used in 1545}

In 1545, vom Berg and Neuber rereleased the Hauspostille and also published its Latin translation (Luther 1545a, 1545b). In these editions, some of the square blocks were reused, but most of the illustrations were impressed from a new set of matrices. It includes 61 rectangular blocks $(70 \times 50 \mathrm{~mm})$, suitable for the pericopes of the winter and summer parts and the Passion scenes. In the vast majority of cases, the themes of the illustrations are strictly related to the respective pericopes, but there are a few exceptions. For instance, as was the case with the 1544 edition, the Fifth Sunday of Lent is not accompanied by the Attempt to stone Christ, but by a rather neutral representation of Christ with the Pharisees ([S 21] and [R 22]). 
There are relatively few anticlerical accents in the rectangular cycle, but they appear in new contexts. In the scene of Christ's conversation with the Pharisees about the greatest commandment, illustrating the pericope for the Eighteenth Sunday after Trinity (Mt 22: 34-46), one of the listeners-the extreme figure on the left-has a tonsure and a monk's habit (Figure 9). This can be seen to refer to a fragment of the sermon in which Luther states that nuns and monks failed to understand the simplicity of the Commandment of Love (Luther 1544, pp. 489-96). The woodcut has no particularly aggressive overtones, but the very presence of a monk-like figure is worth noticing, because in the 1544 cycle the illustration for the same Sunday [S 51] contained no elements alluding to contemporary issues.

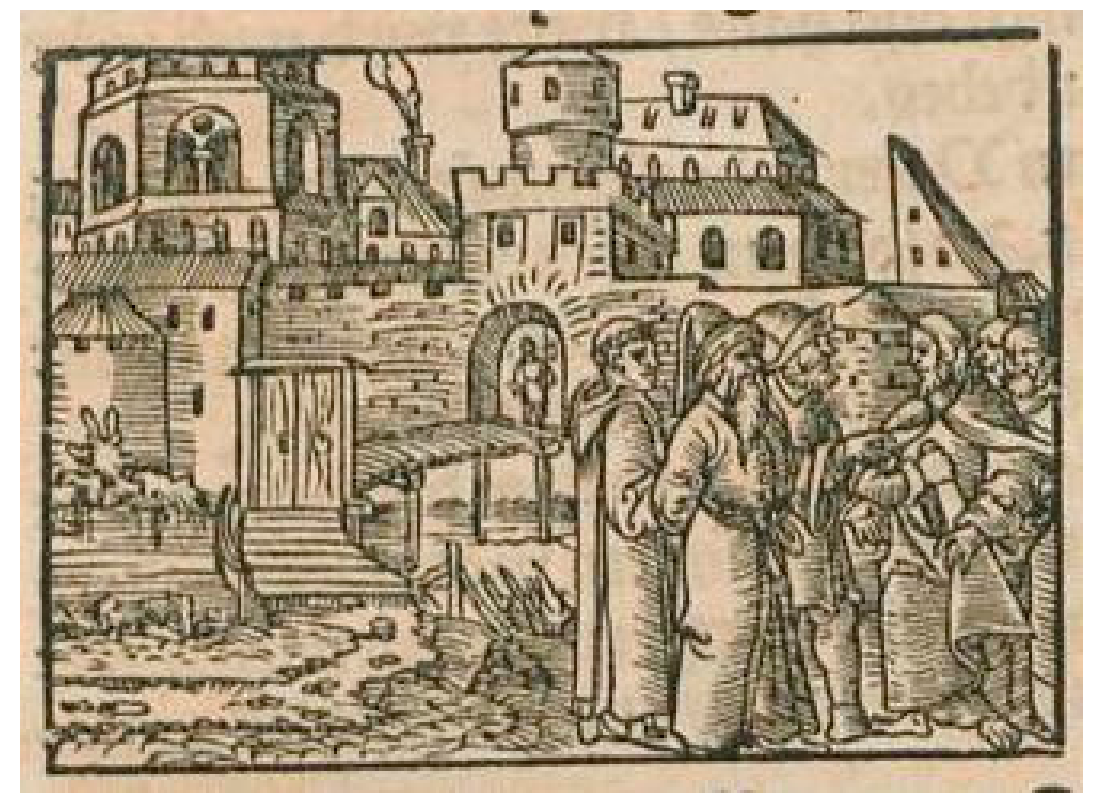

Figure 9. Woodcut recurring in books published by vom Berg and Neuber: Christ and the Pharisees [R 56], in (Luther 1545a, part 2, fol. CXXXIIIv) (Halle, Salle, Universitäts- und Landesbibliothek Sachsen-Anhalt, urn:nbn:de:gbv:3:1-102424).

A figure in monk habit can also be found in the Crucifixion, which illustrates the Eleventh Sermon of the Passion (Figure 10). The allusion to the contemporary Roman Catholic clergy is even more discreet than in the scene of the discussion with the Pharisees, as the figure stands among the onlookers behind the cross of one of the thieves, near the right-hand edge of the composition. In this case too the motif can be seen to refer to the content of the sermon, which elaborates on the priesthood of Christ, emphasizing, among other things, the difference between the Lutherans' and the papists' approach to the matter (Luther 1544, pp. 239-41).

Against this background, the Nailing to the Cross that illustrates the Tenth Passion Sermon, immediately preceding the Crucifixion, definitely stands out (Figure 11a). The woodcut features not Roman soldiers, but the Catholic clergy as Christ's torturers. Their actions are blessed by the Pope, accompanied by a cardinal and other Church dignitaries. One of the design's sources must have been the 1507 woodcut by Hans Baldung Grien or its reversed and reduced copy attributed to a south German (possibly Augsburg) printmaker called "Monogrammist IS with a shovel" (Figure 11b). The arrangement of the cross with Christ's body, the kneeling hooded man nailing Christ's right hand, and the standing female figure bending above Christ's body are the motifs that find close analogies in the woodcut by the Monogrammist IS with a shovel. However, there has also been a significant change of roles and props. Originally, the woman - probably one of the Marys-held her coat with her left hand, while pulling out her right hand to carefully cover Christ's loins with the fabric. In the 1545 woodcut, the person is dressed in a long robe and veil, which allows us to recognize her as a nun. She holds a spear, which is so placed in the composition that it is impossible to judge at the first moment (especially given the woodcut's small size) whether she is leaning on the spear or piercing 
Christ's genitals. In fact, the woman does not actively participate in torturing Christ, but she has some share in nailing him to the cross, as she keeps a basket full of nails in her left hand. It is very significant that it is a woman who has been given such a role, because, according to a late medieval legend, the nails used for Christ's crucifixion were forged by the wife of a blacksmith who refused to perform this task (Schmidt 1985). This motif, described and illustrated in the so-called Holkham Bible Picture Book of ca. 1327-1335 (British Library, Add Ms. 47682, fol. 31r), was also represented in the fifteenth century, one of the most prominent examples being the scene of forging the nails in the foreground of Carrying a Cross in Jean Fouquet's Hours of Étienne Chevalier of ca. 1452-1460 (Chantilly, Musée Condé, MS 71, fol. 78).

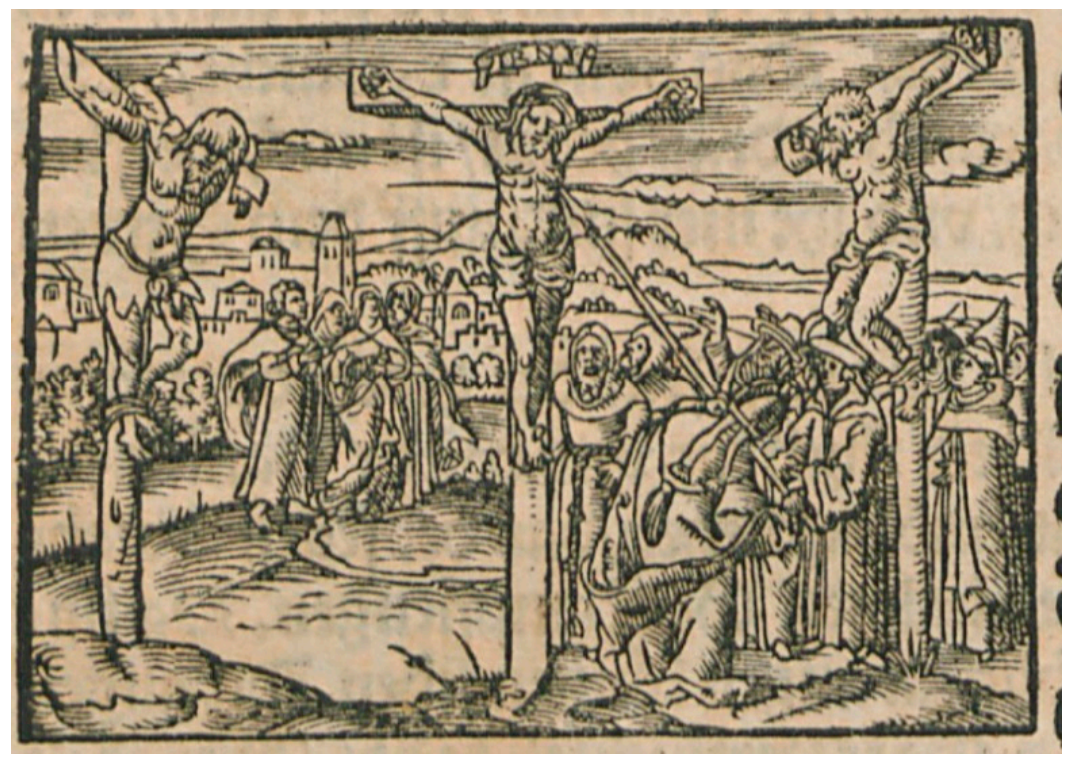

Figure 10. Woodcut recurring in books published by vom Berg and Neuber: Crucifixion [R 29], in (Luther 1545a), fol. CLXIv (Halle, Salle, Universitäts- und Landesbibliothek Sachsen-Anhalt, urn:nbn:de:gbv:3:1-102424).

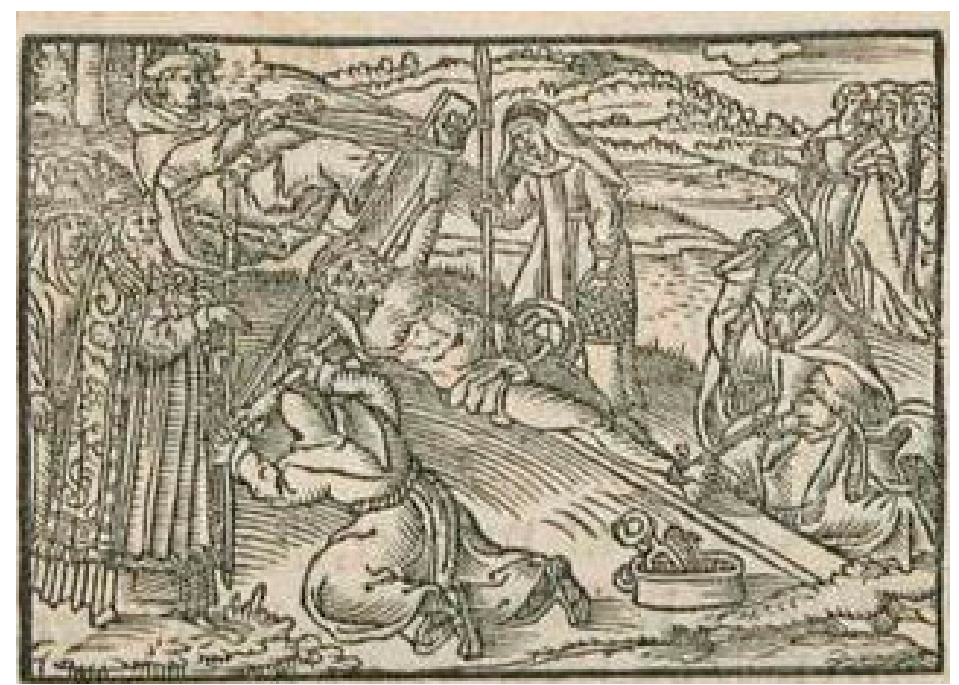

(a)

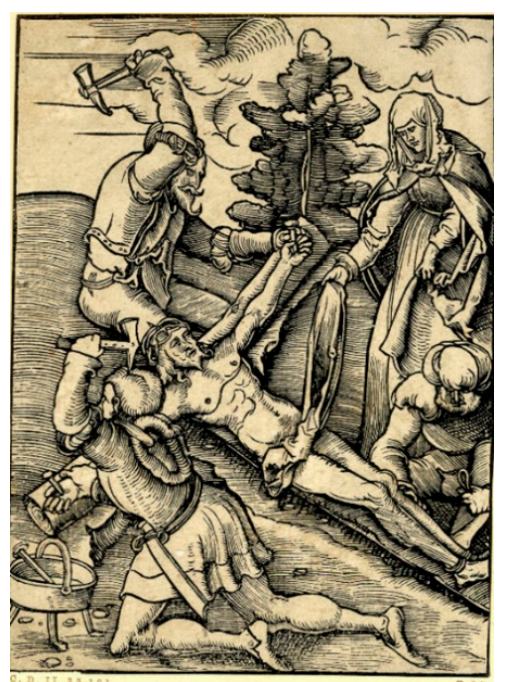

(b)

Figure 11. Christ nailed to the cross: (a) woodcut recurring in books published by vom Berg and Neuber [R 28], in (Luther 1545a), fol. CLVIv (Halle, Salle, Universitäts- und Landesbibliothek Sachsen-Anhalt, urn:nbn:de:gbv:3:1-102424); (b) Monogrammist IS with a shovel, London, the British Museum, asset number 85418001, (C) The Trustees of the British Museum. 


\section{Selection Criteria: Uses of Two Sets between 1544 and 1548}

\subsection{Accumulation, Elimination, and Replacement}

The set of square blocks initially used in the 1544 edition of Luther's Hauspostille edited by Veit Dietrich includes various motifs referring not only to the respective pericopes, but also to the sermons. However, the cycle does not seem to have been designed specifically to illustrate this particular work. Admittedly, some scenes can be linked to the criticism of the papacy also present in Luther's homilies, but such motifs were widespread in both contemporary writings and visual imagery; furthermore, it would be difficult to demonstrate this relation is a cause and effect analogy. More importantly, some scenes are missing in the square block set, even from the point of view of a typical postil series. As has already been mentioned, the cycle lacks such topics as the Circumcision, Ascension, or Attempt to stone Christ, which usually illustrates the pericope for the Fifth Sunday of Lent (J 8: 46-59). Instead, the conversation between Christ and the Pharisees appears in the latter context, with a motif of coin proving that the design was originally conceived as illustration of the discussion about taxes (Mt 22: 15-22) read on the Twenty-Third Sunday after Trinity, and impressed on this occasion too in the 1544 print. Finally, the square set does not cover the Passion cycle, although Dietrich concluded the winter part with a collection of Passion sermons. Some of these deficiencies were corrected in the Hauspostille editions that appeared in the following year with a new set of woodcuts.

In turn, the cycle of rectangular blocks first impressed in 1545, although completed by the Passion scenes, lacked some woodcuts needed for the winter and summer postils and, most importantly, it did not include illustrations of the festival postil. No wonder, then, that matrices of the square cycle were reused to impress respective woodcuts in the 1545 edition of Hauspostille. Therefore, its festival part includes all the scenes with anti-Catholic overtones for the feasts of St Stephen, St Matthew, Saints Peter and Paul, and Saints Simon and Jude. Moreover, in the winter and summer parts also, single square woodcuts were occasionally used, among these the two scenes with an anti-Catholic message- that is, the Communion and procession for Palm Sunday and the Warning against false prophets for the Eighth Sunday after Trinity. As a consequence, the combination of the two cycles contributed to an accumulation of anti-Catholic themes in 1545.

In the following years, the square and rectangular sets were combined several times, not only in editions of Luther's Hauspostille of 1546, 1547, and 1548 (Luther 1546, 1547, 1548), but also in other works published by vom Berg and Neuber. An example is the German translation of the extremely popular prayer book Hortulus animae. In its 1548 edition (Hortulus 1548), the title page shows a rectangular representation of the Risen Christ triumphing over death [R 31]; the first illustration is the square representation of the Holy Trinity with the creation of Adam, the Crucifix, and the Pentecost [S 32], then selected scenes mainly from the rectangular cycle were impressed, and the last woodcut (next to the portrait of Luther, which does not belong to any of the series) is the Warning against false prophets [S 41], which, however, does not refer to its traditional context of the Matthew pericope, but to the quotation from the Second Letter of St Peter (2Pt 2: 1-3), explained as follows: "Dise ernstliche warnung S. Peters sollen wir wol ermessen, wo von der heylige Geyst rede. One zweyffel will er uns damit lehren, die rechten Lehrer von den falschen erkennen. Drumb sollen wir się fleissig mercken."

The 1548 edition of the Hauspostille-dated 1547 in the colophon and 1548 on the title page-is particularly interesting for our argument. At first sight, the layout is similar to that of the 1545 edition, but an attempt to find the woodcuts with anti-Catholic motifs results in a series of disappointments. It is then that the demon disappeared from the scene for Palm Sunday (Figure 1b; (Luther 1548), fol. CVI), and this very motif allows us to solve the discrepancy between the dates as given in the colophon and on the title page. The 1548 date seems more credible, as can be inferred from the fact that the demon is still present over the procession in another publication printed by vom Berg and Neuber in this very year: Veit Dietrich's Summaria for young audiences (Dietrich 1548). Unlike Dietrich's previous Summaria to the Bible (Summaria über die gantze Bibel published several times by vom Berg and Neuber), the text is arranged by liturgical year and illustrated. It does not contain 
an open criticism of the papacy, but among the woodcuts one finds the Warnings against false prophets [S 41], the Stoning of St Stephen [S 58], the Siege of the church [S 72], the juxtaposition of the believers gathered around Christ and the aggressive troops of the Catholic clergy [S 61] and a similar contrast of the two groups flanking the Crucifix [S 65].

In vain does one seek any of these in the 1548 edition of the Hauspostille. In the cases of the feasts of St Stephen and of St Matthew (Luther 1548, fol. XIV and fol. XXXI), the square woodcuts were clearly planned, but ultimately never impressed (Figure 12). In the context of the Eighth Sunday after Trinity, one discovers-instead of the Warning against false prophets from the square set-a neutral representation of Christ among the apostles [R 34] impressed from the rectangular block (Figure 13), which was also used for the feast of Saints Peter and Paul (Luther 1548, part 3, fol. LV). Another neutral representation of Christ with disciples, also from the rectangular series, accompanies the feast of Saints Simon and Jude (Luther 1548, part 3, fol. XCII). Finally, the Nailing to the Cross in the Passion section was replaced by the Crucifixion, subsequently reimpressed in the context of the next sermon (Luther 1548, fol. CLVIv and fol. CLXIv). This brief survey leads to a conclusion that the 1548 edition of the Hauspostille was consistently-although sometimes as if at the last minute-deprived of polemical threads.

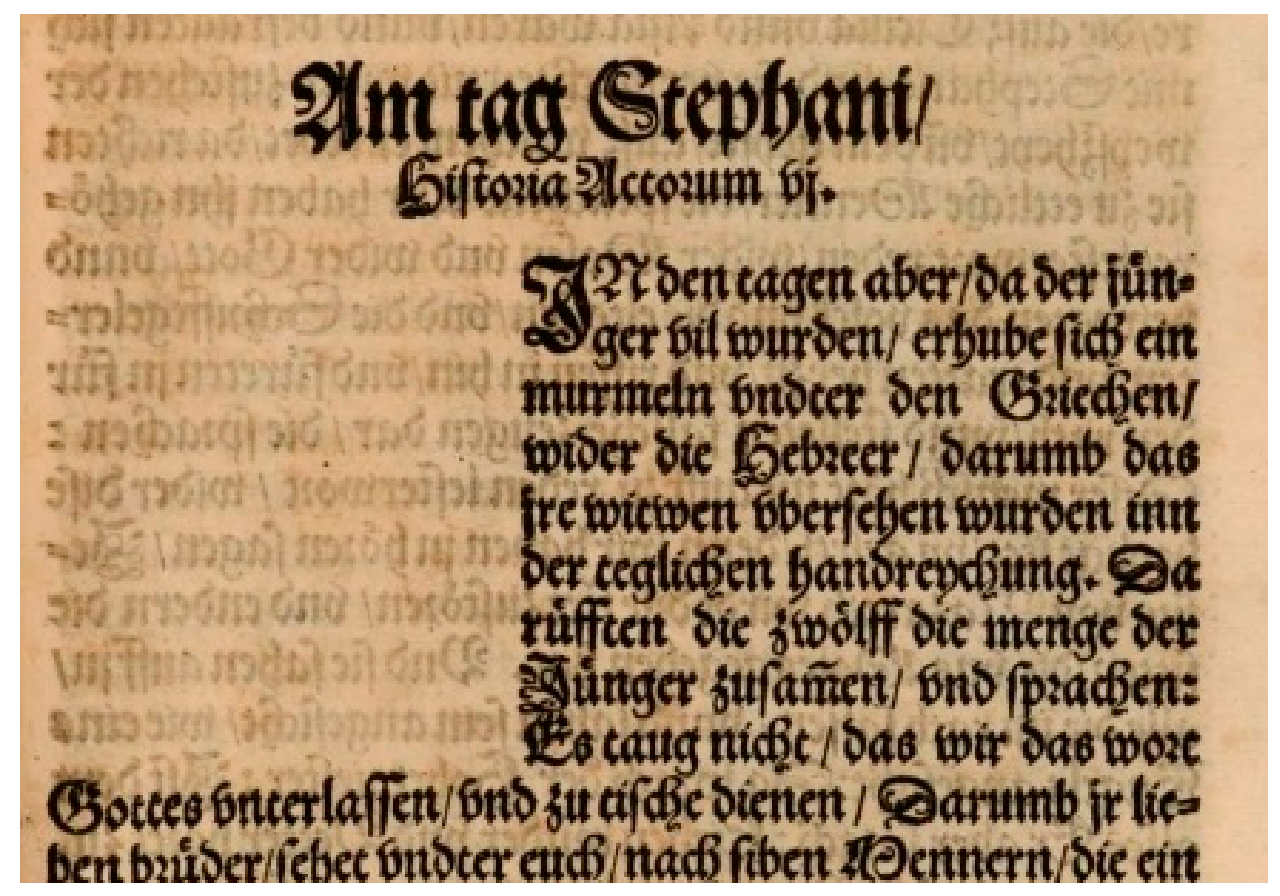

Figure 12. Empty space next to the pericope for St Stephen's feast in (Luther 1548, part 3, fol. XIV) (Munich, Bayerische Staatsbibliothek, 2 Hom. 281, urn:nbn:de:bvb:12-bsb10144040-5; NoC-NC/1.0). 


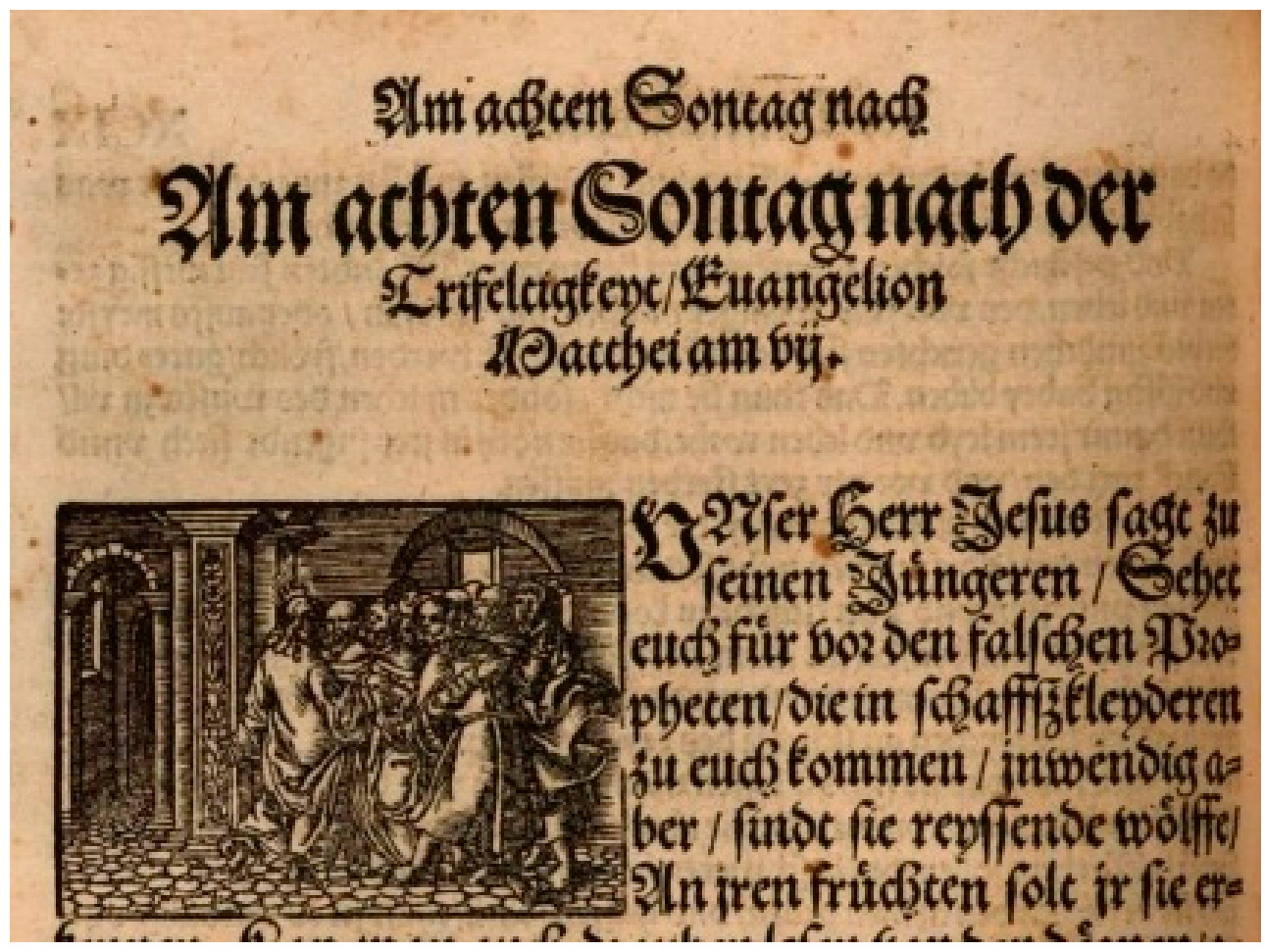

Figure 13. Christ with disciples [R 34] next to the pericope for the Eighth Sunday after Trinity in (Luther 1548, part 2, fol. XCIXv) (Munich, Bayerische Staatsbibliothek, 2 Hom. 281, urn:nbn:de:bvb:12-bsb10144040-5; NoC-NC/1.0).

\subsection{Nuremberg between 1544 and 1548}

The changing attitude to the anticlerical motifs in the subsequent editions of Luther's Hauspostille may be explained against the background of the current situation in the empire and especially in the town of Nuremberg.

The introduction of such motifs in 1544 is rather unsurprising in terms of the historical period, but needs a closer examination with respect to the genre of the publication and, particularly, the milieu in which it was printed. Various pictorial anti-Pope satires can be found in the visual culture of the German Reformation at least from the 1520s, and they become quite common in the 1540s (Scribner [1981] 1994). However, the typical ammunition in this propaganda war was not large volumes, but one-page pamphlets or small brochures - cheap, easy, and quick to distribute, and, therefore, able to reach a wide audience. Spectacular yet only isolated examples can be traced in larger and, thus, much more expensive prints, such as bibles or postils. Overtly anticlerical or anti-Catholic images occasionally had appeared, as already mentioned, in Luther's translation of the Bible and in his Kirchenpostille. In turn, the Catholic prints sometimes included affirmative allusions to the Church hierarchy, such as God the Father represented in the papal tiara on the title page of the New Testament edited by Hieronymus Emser (Naw Testament 1527) or St Peter in the tiara in Johannes Eck's postils (Eck 1530-1531). However, giving God the Father or even St Peter the attributes of papal authority stems from the medieval tradition, also it does not necessarily have to be regarded as an anti-Protestant demonstration.

The appearance of anticlerical scenes in Luther's Hauspostille, especially in such number, is noteworthy, because illustrations of early modern postils only occasionally include polemic accents. True, each postil was written for the representatives of a particular confession, but some publications were subsequently used by followers of another Christian denomination (Frymire 2010, p. 131). Moreover, even if the sermons include motifs implicitly or explicitly referring to the contemporary religious controversies, the illustrations usually refer to the pericopes rather than to the homilies. As a consequence, the cycle of woodcuts is analogous or even identical in the Catholic and Protestant collections, especially in the winter and summer postils. More significant differences may be observed 
in the festival postils, as the Lutheran collections usually only cover feasts of Christ, Mary, and biblical saints, while the Catholic postils also commemorate various popular saints absent in the Bible and acknowledge typical Catholic holidays (although some Lutheran postils include sermons for the Corpus Christi and the Assumption of Mary).

The appearance of such a number of outspoken anticlerical motifs in the first edition of Luther's Hauspostille printed in Nuremberg in 1544, and the further development of this thread in the edition of 1545 , can be explained by reference to current urban policy. Nuremberg, a free city of the empire (freie Reichsstadt), was among the first to opt for the Reformation as early as the turn of 1521/1522. One of the most prominent champions of the Reformation, Andreas Osiander, was appointed to St Lawrence's Church (Lorenzkirche) in Nuremberg in 1522. Soon, he gained wide publicity in the Reich, and Veit Dietrich was among his local supporters (Hamm 2004). In the following years, liturgical changes began in the town (1523), Luther's Deutsche Messe was introduced (1524), the Latin Mass and Catholic sermons were banned (1525), and monasteries were closed (Schindling 1989). In theological terms, Nuremberg remained closely associated with Wittenberg (Wandel 2006). In 1530, the city adopted the Augsburg Confession, and in the early 1530s, Nuremberg formed alliances with two other Reich cities, Augsburg and Ulm, to defend against any possible attack (Close 2000, pp. 61-69; Schmidt 1984). However, Nuremberg-like Augsburg and unlike Ulm-did not join the emerging Schmalkaldic League, having in mind good relations with the emperor (Close 2000, p. 71). Also the medieval furnishing, despite some rearrangements, was still maintained in the Nuremberg churches (Nürnberger Ratsverlässe 1904, n. 3664 and 3665; Seebaß 1997).

At the time when the first edition of the Hauspostille was being prepared, the relations between the Schmalkaldic League and the emperor deteriorated rapidly. The League got involved in an issue between the Catholic Duke Henry of Brunswick-Wolfenbüttel and the Protestant town of Goslar. In the summer of 1542, the troops of the League's leaders, Philip of Hessen and Johann Frederick of Saxony, entered the duchy (Brady 1995; Brady 1983; Close 2000, pp. 75-77). Henry took refuge in Bavaria and put the League on trial before the Imperial Chamber Court (Reichskammergericht). Military intervention not only threatened to provoke the emperor's revenge, but also revealed the incoherence within the League itself. Some Protestant rulers (like those of Pomerania) took Henry's side (Ptaszyński 2017, pp. 57-58), while the southern towns were reluctant to bear the financial burden of the conflict. Avoiding a stronger involvement in the Schmalkaldic League's politics, the authorities of Nuremberg, Augsburg, and Ulm rejected Donauwörth's offer to join the Three Cities' League in 1544 (Close 2000, pp. 131-34). The strengthened position of the emperor, after he had made peace with Francis of France in Crépy (18 September 1544), was also a cause for caution. Closing the Italian wars, which had been going on for several decades, enabled Charles V's involvement in the internal politics of the empire and allowed the Council of Trent to begin its proceedings the following year (Jedin 1949). At that time, Osiander wrote from Nuremberg to the first Lutheran pastor at St Elisabeth church in Breslau, Ambrosius Moibanus: "If [this is true], they are undoubtedly preparing war against us" (Sed adhuc incertum est, an vera sit. Si est, haud dubie bellum molientur adversum nostros-Osiander 1990, n. 321, pp. 358-61).

In light of current political events, the illustrations in the first edition of Luther's Hauspostille take on a particular meaning. In the foreword, placed after a short preface by Luther, Dietrich addresses the Nuremberg council, warning them against disorder and chaos. "Error, disunity, and sects: Veit Dietrich had provided a sensitive Obrigkeit with nothing less than code words for disobedience and rebellion, the prevention of which was ensured most effectively by the strict control of discourse" (Frymire 2010, pp. 93-94). This attachment to the unity of doctrine, probably directed against the Anabaptists and adherents of the radical Reformation, could have been seen as the hallmark of Nuremberg as a decent and deeply Christian city. This idea was reinforced by the full-page woodcut placed directly after Dietrich's foreword: Albrecht Dürer's Sancta Iusticia (Figure 14). The woodcut that depicts the Imperial Adler (Eagle) flanked by two coats of arms of Nuremberg and by angels bearing the attributes Iustitia, Temperantia, Liberalitas, and Caritas was designed in 1521 and first impressed on the verso of the title 
page of the 1522 edition of the Nuremberg constitution (Reformacion Stat Nüremberg 1522; Zapalac 1990; Von Friedeburg 2002; Schoch Rainer and Scherbaum 2004, p. 165, n. 273.5).

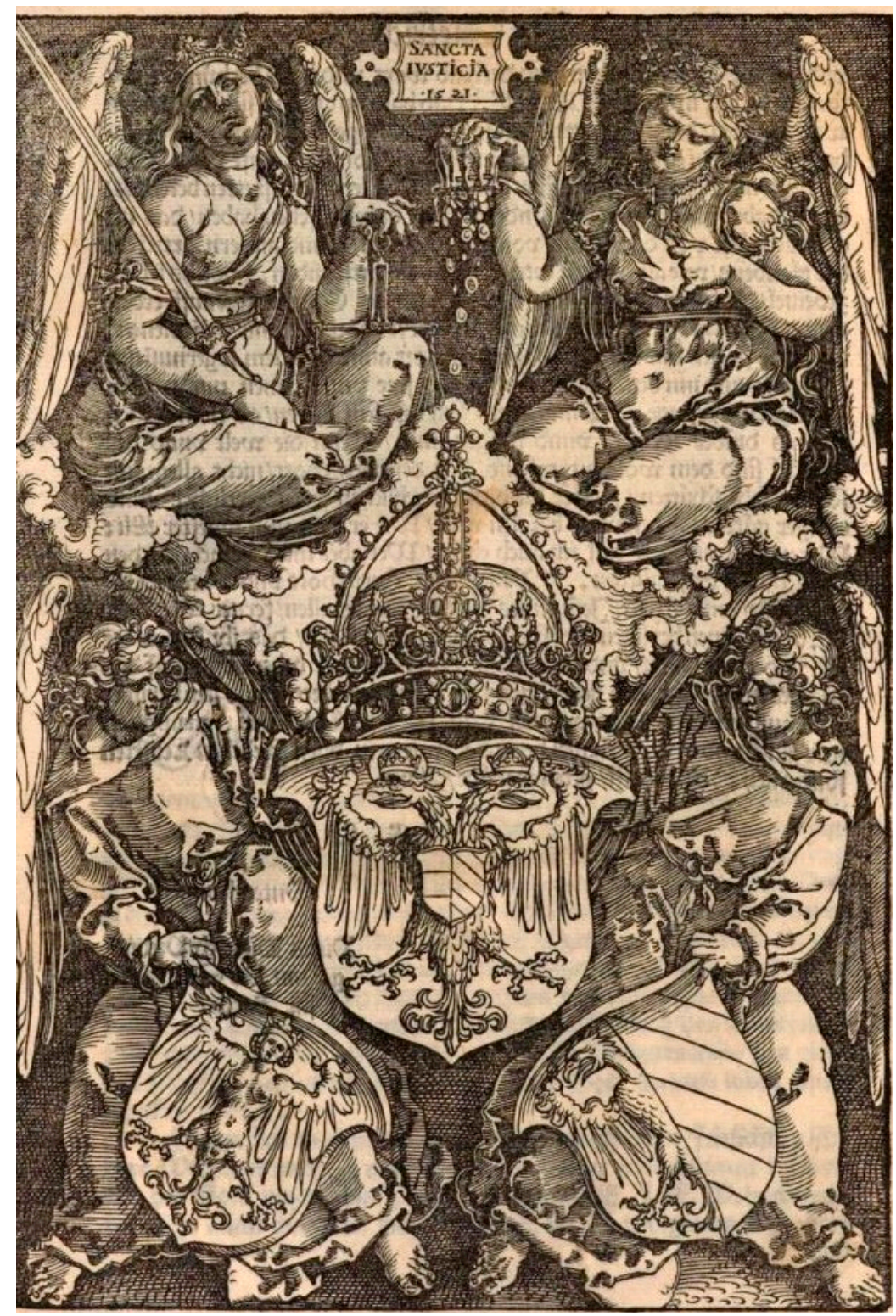

Figure 14. Albrecht Dürer, Sancta Iusticia, woodcut, 1521. in (Luther 1544b, fol. vi]v) (Munich, Bayerische Staatsbibliothek, 2 Hom. 277, urn:nbn:de:bvb:12-bsb10144039-2; NoC-NC/1.0).

Reusing Dürer's block in the opening section of the 1544 edition of the Hauspostille might be read as an element of the cautious policy of the city authorities vis-à-vis Charles V, or as a manifestation of the position of Nuremberg as a free city of the empire. Yet, the cycle of further illustrations with several anti-Catholic motifs seems rather a call for nonconformism and an unequivocal statement on the part of the Schmalkaldic League in the escalating conflict with the emperor. From this point of view, if the choice was between the Antichrist and the Gospel, Nuremberg should no longer hesitate. The preserved fragments of Andreas Osiander's sermons delivered in 1543 prove that there were in fact issues between pastors, who also dictated secular norms of behaviour, and the town council, which accused the preachers of inciting social unrest (Osiander 1990, n. 301, pp. 118-21). Moreover, in 1544 Osiander published the famous but controversial work Coniecturae de ultimis temporibus ac de fine mundi, in which he predicted the imminent end of the world and denounced the Roman Church as 
the Antichrist (Osiander 1990, n. 306/315, pp. 150-271). Soon, the Nuremberg theologians repeated similar ideas in their negative opinions about the inauguration of the Council of Trent (Osiander 1990, n. 319, p. 339).

The clash with the emperor ended in a rapid defeat of the Protestant alliance. After the first triumphs, the Schmalkaldic League troops were beaten at the Battle of Mühlberg (24 April 1547), the leaders were imprisoned and Charles V dictated conditions of peace at the Diet of Augsburg that were humiliating to the Protestants (Schorn-Schütte 2005). The imperial decree known as the Augsburg Interim provided that the Lutherans may preserve the Eucharist under two kinds and the marriage of priests in the territories where these had already been practised, but on the other hand they were obliged to reintroduce the cult of saints, the traditional liturgical calendar and other ceremonies (Mehlhausen 1970). The Augsburg Interim immediately provoked protests by the Lutheran clergy and a ruthless publicity struggle in the empire (Dingel 2010; Schorn-Schütte 2015). The Magdeburg fortress, which refused to accept the imperial document and was besieged by Catholic coalition troops, became the symbol of resistance (Kaufmann 2003). In Nuremberg too, as in many Protestant cities, the situation was very tense.

On the one hand, the city authorities were forced to give in to political pressure from the emperor; on the other hand, the clergy kept calling for disobedience and perseverance in faith. Already at the beginning of the war, in 1546, Osiander had issued a sermon that entitled the lower magistrates-that is, town authorities or princes-to disobey the imperial rule in order to defend their subjects (Osiander 1990, n. 335-36, pp. 477-87). Osiander argued that a ruler defending a false religion becomes a tyrant awaiting God's punishment and, therefore, there is no obligation to obey him. The memory of this preaching made it very difficult for the city council to reach an agreement with the emperor. Nevertheless, the Nuremberg pastors took an intransigent stance on the imperial order, even though the city council considered that political circumstances did not allow an unequivocal rejection of the Interim and could only delay the execution of certain provisions. Rejecting these attempts at compromise, the Nuremberg pastors not only announced a negative opinion on the Interim, but also produced a series of writings in the apocalyptic spirit, again portraying the Pope as the Antichrist (Osiander 1990, n. 344-45, pp. 504-48; Stupperich 1973; Pfeiffer 1986; Strobel 1772, pp. 128-140; Hirsch 1750, pp. 17-111). In response, however, the city council officially banned the clergy from preaching on the Interim, and officially accepted the document on 20 June 1548 (Bub 1924). This led to the resignation of Osiander on 6 November 1548, who went to Prussia, where he took over the chair at the University of Königsberg. In such circumstances, the hasty removal of anti-Pope motifs from the 1548 edition of the Hauspostille should not come as a surprise. The printers certainly did not want to risk the confiscation of the edition that the city council could have imposed, reading every attack on the Catholic Church as a polemic around the Augsburg Interim (Nürnberger Ratsverlässe 1904, n. 3010).

\section{Aftermath: Further Cycles and Reuses after 1548}

Thus, the anti-Catholic message introduced to the illustrations of the Hauspostille in 1544, and strengthened in 1545, were eliminated from the 1548 edition, although the number of matrices available to the printers had become significantly enriched. In the years to come, vom Berg and Neuber further developed the stock of woodcut blocks they used and the repertoire of postils they published. From the 1550s, they occasionally used two small-format cycles of rather inconspicuous blocks (Huberinus 1555; Melanchthon 1555). More importantly, from 1549 they had at their disposal the above-mentioned series designed in 1544 by Hans Brosamer (Knauer 2015). Brosamer's woodcuts were distinguished not only by their quality, but also by the dimensions, approx. $105 \times 142 \mathrm{~mm}$, appropriate to publications in folio. Vom Berg and Neuber used these blocks to illustrate Luther's Hauspostille (Luther 1549), but this cycle only included woodcuts for the Gospel pericopes of winter and summer postils; it also lacked an image that would be appropriate for the reading from the First Letter to the Corinthians, the Passion scenes, and separate illustrations for the saints' feasts. No wonder then 
that vom Berg and Neuber drew on the old stock again, but one has to investigate which scenes were chosen and which omitted, placing emphasis on those that originally gave the Haustpostille decoration an anti-Catholic allure.

In the winter postil, the Palm Sunday pericope on fol. CXI is invariably accompanied by the Eucharist and procession, but without the silhouette of a demon the woodcut lost its polemical potential. The Passion cycle, preceded by the square Christ washing the feet of the disciples [S 23], includes the scenes from the rectangular blocks, again without the controversial Nailing to the cross [R 28], consistently replaced by the Crucifixion [R 29] impressed twice on fol. CLXII and CLXVII. The summer postil needed no additions, but it has to be noted that Brosamer's Warning against false prophets [H 1047] has no anti-Catholic accents (fol. CIIIv). In the festival postil, vom Berg and Neuber-like the first user of Brosamer's series, Nicolaus Wolrab (Luther 1544c)—reimpressed some scenes they found appropriate, but also complemented the series using smaller blocks. Thus, Brosamer's Christ calming the storm on the Sea of Galilee [H 1015] became the Vocation of the Apostles Peter and Andrew, as this event also took place on the lake (fol. II); the Circumcision of Christ [H 1010] became the Circumcision of St John the Baptist (fol. XLVIIv); and Christ and the Pharisees with a scene of stoning of a prophet in the background [H 1007] was substituted for St Stephen's stoning (fol. XV). Out of nine square and two rectangular blocks from older series, some refer directly to the pericope or to the person commemorated on a given day, while others enrich the repertoire of generic representations of Christ preaching. Consistently, and possibly not coincidentally, no scenes with anticlerical meaning reappeared in this edition of the Hauspostille. The feasts that in 1544 and 1545 were accompanied by woodcuts with polemical accents—St Matthew's, Saints Peter and Paul's, and Saints Simon and Jude's—were assigned neutral illustrations showing Christ among the apostles, either from Brosamer's cycle ([H 1033] on fol. XXXIIv and [H 1031] on fol. LVII), or from the rectangular set ([R 35] on fol. XCIVv).

All three sets of blocks were then used in numerous vom Berg and Neuber prints. To some extent the choice of illustrations in particular works must have depended on material conditions. Brosamer's cycle, due to its size, might only be used in the folio prints. Among these were not only subsequent editions of the Hauspostille (Luther 1553, 1554, 1555), but also Luther's Kirchenpostille (Luther 1560), Dietrich's Kinderpostilla (Dietrich 1549) and Johann Spangenberg's postil (Spangenberg 1554, 1559, 1564) and its translation into Czech (Spangenberg 1557). Brosamer's series was often supplemented by smaller woodcuts that could illustrate prints in various formats. The square and rectangular blocks were used, for instance, in Johannes Mathesius's and Konrad Cordatus's postils, printed in octavo (Mathesius 1558; Cordatus 1554) or in Hieronimus Weller's postil, printed in folio (Weller 1559). The only application of biblical teachings to contemporary circumstances in this collection is Christ's conversation with the Pharisees [R 56], one of whom clearly has a tonsure and habit. However, this does not mean that the anti-Catholic motifs completely disappeared from vom Berg and Neuber's prints after 1548. They returned, for instance, in subsequent editions of Dietrich's Summaria (e.g., Dietrich 1555). Some can also be found in the 1552 edition of Philip Melanchthon's postil translated by Johann Pollicarius. In its winter and summer parts rectangular illustrations are included: the Eighth Sunday after Trinity is accompanied by a neutral scene of Christ's conversation with the apostles [R 34], even though there are references to papal superstitions in the sermon (Melanchthon 1552, fol. LXXXIII). Yet in the festival postil some square scenes were impressed, among them the Stoning of St Stephen [S 58].

If one accepts that the elimination of anticlerical motifs in 1548 coinciding with the disputes over the Augsburg Interim is no mere accident, then their reintroduction after 1549 may be explained in the context of the dynamics of this controversy. After twelve months or so, the issue lost its original impetus. Each of the territories and cities forced to accept the Interim took its own way of dealing with the imperial document. What is more, the anti-emperor coalition, which Maurice, Elector of Saxony, also joined, was renewed quite quickly. Eventually, in 1552, the coalition forced the emperor to adopt a new agreement in Passau, making the Interim a dead letter. 
Author Contributions: Conceptualization, G.J.; Methodology, G.J.; Investigation, G.J., M.P.; Data Curation, G.J.; Writing-Original Draft Preparation, G.J., M.P.; Writing—Review and Editing, G.J.; Visualization, G.J. All authors have read and agreed to the published version of the manuscript.

Funding: This research was funded by the NATIONAL SCIENCE CENTRE, POLAND, grant number 2018/31/B/HS2/00533

Conflicts of Interest: The authors declare no conflict of interest.

Appendix A. Illustrations in Selected Editions of the Hauspostille of 1544, 1545, 1548 and 1549

\begin{tabular}{|l|l|}
\hline & Older blocks \\
\hline & $\begin{array}{l}\text { Square blocks first used in 1544; [S no] = square block } \\
\text { number }\end{array}$ \\
\hline & $\begin{array}{l}\text { Rectangular blocks first used in 1545; }[\mathrm{R} \text { no] }]= \\
\text { rectangular block number }\end{array}$ \\
\hline & $\begin{array}{l}\text { Brosamer's 1544 blocks first used in Nuremberg in } \\
1549 ;[\mathrm{H} \text { no] }=\text { block number (after Knauer 2015) }\end{array}$ \\
\hline
\end{tabular}

\begin{tabular}{|c|c|c|c|c|c|}
\hline Feast & Pericope & Luther $1544 b$ & Luther 1545a & Luther 1548 & Luther 1549 \\
\hline \multicolumn{6}{|c|}{ Winter postil } \\
\hline $\begin{array}{l}\text { 1st Sunday of } \\
\text { Advent }\end{array}$ & Mt 21: 1-9 & $\begin{array}{l}\text { Entry to } \\
\text { Jerusalem [S 1], } \\
\text { fol. Iv }\end{array}$ & $\begin{array}{l}\text { Entry to } \\
\text { Jerusalem [R 1], } \\
\text { fol. Iv }\end{array}$ & $\begin{array}{l}\text { Entry to } \\
\text { Jerusalem [R 1], } \\
\text { fol. Iv }\end{array}$ & $\begin{array}{l}\text { Entry to } \\
\text { Jerusalem, fol. } \\
\text { Iv }\end{array}$ \\
\hline $\begin{array}{l}\text { 2nd Sunday of } \\
\text { Advent }\end{array}$ & Lk 21: 25-33 & $\begin{array}{l}\text { Prophecy of the } \\
\text { Last Judgment } \\
\text { [S 2], fol. IV }\end{array}$ & $\begin{array}{l}\text { Prophecy of the } \\
\text { Last Judgment } \\
\text { [R 2], fol. IVv }\end{array}$ & $\begin{array}{l}\text { Prophecy of the } \\
\text { Last Judgment } \\
\text { [R 2], fol. IVv }\end{array}$ & $\begin{array}{l}\text { Prophecy of the } \\
\text { Last Judgment } \\
\text { [H 1001], fol. V }\end{array}$ \\
\hline $\begin{array}{l}\text { 3rd Sunday of } \\
\text { Advent }\end{array}$ & Mt 11: 2-10 & $\begin{array}{l}\text { St John the } \\
\text { Baptist in } \\
\text { prison [S 3], fol. } \\
\text { VII }\end{array}$ & $\begin{array}{l}\text { St John, } \\
\text { the Baptist in } \\
\text { prison [R 3], fol. } \\
\text { VIIIv }\end{array}$ & $\begin{array}{l}\text { St John, } \\
\text { the Baptist in } \\
\text { prison [R 3], fol. } \\
\text { VIIIv }\end{array}$ & $\begin{array}{l}\text { St John, } \\
\text { the Baptist in } \\
\text { prison [H 1002], } \\
\text { fol. IX }\end{array}$ \\
\hline $\begin{array}{l}\text { 4th Sunday of } \\
\text { Advent }\end{array}$ & J 1: 19-28 & $\begin{array}{l}\text { St John } \\
\text { baptizing [S 4], } \\
\text { fol. } X\end{array}$ & $\begin{array}{l}\text { St John } \\
\text { baptizing [R 4], } \\
\text { fol. XIIv }\end{array}$ & $\begin{array}{l}\text { St John } \\
\text { baptizing [R 4], } \\
\text { fol. XIIv }\end{array}$ & $\begin{array}{l}\text { St John } \\
\text { baptizing [H } \\
\text { 1003], fol. XIIIv }\end{array}$ \\
\hline \multirow[b]{2}{*}{$\begin{array}{l}\text { Nativity of } \\
\text { Christ }\end{array}$} & Lk 2: 1-14 & $\begin{array}{l}\text { Nativity of } \\
\text { Christ [S 5], fol. } \\
\text { XIII }\end{array}$ & $\begin{array}{l}\text { Nativity of } \\
\text { Christ [R 5], fol. } \\
\text { XVIv }\end{array}$ & $\begin{array}{l}\text { Nativity of } \\
\text { Christ [R 5], fol. } \\
\text { XVIv }\end{array}$ & $\begin{array}{l}\text { Nativity of } \\
\text { Christ [H 1004], } \\
\text { fol. XVIIv }\end{array}$ \\
\hline & & & & & $\begin{array}{l}\text { Adoration of } \\
\text { the Shepherds } \\
\text { [H 1005], fol. } \\
\text { XXIX }\end{array}$ \\
\hline $\begin{array}{l}\text { Sunday after } \\
\text { Nativity }\end{array}$ & Lk 2: 33-40 & $\begin{array}{l}\text { Presentation of } \\
\text { Christ [S 6], fol. } \\
\text { XXIV }\end{array}$ & $\begin{array}{l}\text { Presentation of } \\
\text { Christ [R 6], fol. } \\
\text { XXXI }\end{array}$ & $\begin{array}{l}\text { Presentation of } \\
\text { Christ [R 6], fol. } \\
{[\text { X]XXI }}\end{array}$ & $\begin{array}{l}\text { Presentation of } \\
\text { Christ [H 1009], } \\
\text { fol. XXXII }\end{array}$ \\
\hline Circumcision & Lk 2: 21 & $\begin{array}{l}\text { Circumcision, } \\
\text { fol. XXVIIIv }\end{array}$ & $\begin{array}{l}\text { Circumcision } \\
{[R \text { 7], fol. XLv }}\end{array}$ & $\begin{array}{l}\text { Circumcision } \\
\text { [R 7], fol. XLv }\end{array}$ & $\begin{array}{l}\text { Circumcision } \\
\text { [H 1010], fol. } \\
\text { XLII }\end{array}$ \\
\hline Epiphany & Mt 2: 1-12 & $\begin{array}{l}\text { Adoration of } \\
\text { the Magi [S 7], } \\
\text { fol. XXXIIIv }\end{array}$ & $\begin{array}{l}\text { Adoration of } \\
\text { the Magi [R 8], } \\
\text { fol. XLIII }\end{array}$ & $\begin{array}{l}\text { Adoration of } \\
\text { the Magi [R 8], } \\
\text { fol. XLIII }\end{array}$ & $\begin{array}{l}\text { Adoration of } \\
\text { the Magi [H } \\
\text { 1011], fol. XLV }\end{array}$ \\
\hline
\end{tabular}




\begin{tabular}{|c|c|c|c|c|c|}
\hline Feast & Pericope & Luther $1544 b$ & Luther 1545a & Luther 1548 & Luther 1549 \\
\hline & Mt 3: 13-17 & $\begin{array}{l}\text { Baptism of } \\
\text { Christ [S 8], fol. } \\
\text { XXXVIIv }\end{array}$ & $\begin{array}{l}\text { Baptism of } \\
\text { Christ [R 9], fol. } \\
\text { XLVIII }\end{array}$ & $\begin{array}{l}\text { Baptism of } \\
\text { Christ [R 9], fol. } \\
\text { XLVIII }\end{array}$ & $\begin{array}{l}\text { Christ talking } \\
\text { to Nicodemus } \\
\text { and St John } \\
\text { baptizing [H } \\
\text { 1039], fol. L }\end{array}$ \\
\hline $\begin{array}{l}\text { 1st Sunday } \\
\text { after Epiphany }\end{array}$ & Lk 2: 42-52 & $\begin{array}{l}\text { Twelve-years-old } \\
\text { Christ in the } \\
\text { Temple [S 9], } \\
\text { fol. XLv }\end{array}$ & $\begin{array}{l}\text { Twelve-years-old } \\
\text { Christ in the } \\
\text { Temple [R 10], } \\
\text { fol. LIv }\end{array}$ & $\begin{array}{l}\text { Twelve-years-old } \\
\text { Christ in the } \\
\text { Temple [R 10], } \\
\text { fol. LIv }\end{array}$ & $\begin{array}{l}\text { Twelve-years-old } \\
\text { Christ in the } \\
\text { Temple [H } \\
\text { 1012], fol. LIIIv }\end{array}$ \\
\hline $\begin{array}{l}\text { 2nd Sunday } \\
\text { after Epiphany }\end{array}$ & J 2: 1-11 & $\begin{array}{l}\text { Marriage at } \\
\text { Cana [S 10], fol. } \\
\text { XLIII }\end{array}$ & $\begin{array}{l}\text { Marriage at } \\
\text { Cana [R 11], fol. } \\
\text { LIVv }\end{array}$ & $\begin{array}{l}\text { Marriage at } \\
\text { Cana [R 11], fol. } \\
\text { LIVv }\end{array}$ & $\begin{array}{l}\text { Marriage at } \\
\text { Cana [H 1013], } \\
\text { fol. LVII }\end{array}$ \\
\hline $\begin{array}{l}\text { 3rd Sunday } \\
\text { after Epiphany }\end{array}$ & Mt 8: 1-13 & $\begin{array}{l}\text { Centurion of } \\
\text { Capernaum [S } \\
\text { 11], fol. XLVv }\end{array}$ & $\begin{array}{l}\text { Centurion of } \\
\text { Capernaum [R } \\
\text { 12], fol. LVIII }\end{array}$ & $\begin{array}{l}\text { Centurion of } \\
\text { Capernaum [R } \\
\text { 12], fol. LVIII } \\
\end{array}$ & $\begin{array}{l}\text { Centurion of } \\
\text { Capernaum [H } \\
\text { 1014], fol. LXI } \\
\end{array}$ \\
\hline $\begin{array}{l}\text { 4th Sunday } \\
\text { after Epiphany }\end{array}$ & Mt 8: 23-27 & $\begin{array}{l}\text { Christ calming } \\
\text { the storm [S 12], } \\
\text { fol. XLVIIIv }\end{array}$ & $\begin{array}{l}\text { Christ calming } \\
\text { the storm [R } \\
\text { 13], fol. LXIv }\end{array}$ & $\begin{array}{l}\text { Christ calming } \\
\text { the storm [R } \\
\text { 13], fol. LXIv }\end{array}$ & $\begin{array}{l}\text { Christ calming } \\
\text { the storm [H } \\
\text { 1015], fol. } \\
\text { LXIVv }\end{array}$ \\
\hline $\begin{array}{l}\text { 5th Sunday } \\
\text { after Epiphany }\end{array}$ & Mt 13: 24-30 & $\begin{array}{l}\text { Parable of the } \\
\text { tares [S 13], fol. } \\
\text { LIv }\end{array}$ & $\begin{array}{l}\text { Parable of the } \\
\text { tares [R 14], fol. } \\
\text { LXV }\end{array}$ & $\begin{array}{l}\text { Parable of the } \\
\text { tares [R 14], fol. } \\
\text { LXV }\end{array}$ & $\begin{array}{l}\text { Parable of the } \\
\text { tares [H 1016] }\end{array}$ \\
\hline $\begin{array}{l}\text { Sunday } \\
\text { Septagesimae }\end{array}$ & Mt 20: 1-16 & $\begin{array}{l}\text { Parable of the } \\
\text { workers in the } \\
\text { vineyard [S 14], } \\
\text { fol. LIV }\end{array}$ & $\begin{array}{l}\text { Parable of the } \\
\text { workers in the } \\
\text { vineyard [R 15], } \\
\text { fol. LXIX }\end{array}$ & $\begin{array}{l}\text { Parable of the } \\
\text { workers in the } \\
\text { vineyard [R 15], } \\
\text { fol. LXIX }\end{array}$ & $\begin{array}{l}\text { Parable of the } \\
\text { workers in the } \\
\text { vineyard [H } \\
\text { 1017], fol. } \\
\text { LXXIv }\end{array}$ \\
\hline $\begin{array}{l}\text { Sunday } \\
\text { Sexagesimae }\end{array}$ & Lk 8: 5-15 & $\begin{array}{l}\text { Parable of the } \\
\text { sower [S 15], } \\
\text { fol. LVII }\end{array}$ & $\begin{array}{l}\text { Parable of the } \\
\text { sower [R 16], } \\
\text { fol. LXXII }\end{array}$ & $\begin{array}{l}\text { Parable of the } \\
\text { sower [R 16], } \\
\text { fol. LXXII }\end{array}$ & $\begin{array}{l}\text { Parable of the } \\
\text { sower [H 1018], } \\
\text { fol. LXXVv }\end{array}$ \\
\hline $\begin{array}{l}\text { Purification of } \\
\text { Mary }\end{array}$ & Lk 2: 22-24 & $\begin{array}{l}\text { Presentation of } \\
\text { Christ [S 6], fol. } \\
\text { LX }\end{array}$ & $\begin{array}{l}\text { Presentation of } \\
\text { Christ [R 6], fol. } \\
\text { CXXVv }\end{array}$ & $\begin{array}{l}\text { Presentation of } \\
\text { Christ [R 6], fol. } \\
\text { CXXVv }\end{array}$ & $\begin{array}{l}\text { Presentation of } \\
\text { Christ [H 1009], } \\
\text { fol. LXXIX }\end{array}$ \\
\hline $\begin{array}{l}\text { Sunday } \\
\text { Quinquagesimae }\end{array}$ & Lk 18: 31-43 & $\begin{array}{l}\text { Healing of the } \\
\text { blind man of } \\
\text { Jericho [S 16], } \\
\text { fol. LXVIv }\end{array}$ & $\begin{array}{l}\text { Healing of the } \\
\text { blind man of } \\
\text { Jericho [R 17], } \\
\text { fol. LXXXIIIv }\end{array}$ & $\begin{array}{l}\text { Healing of the } \\
\text { blind man of } \\
\text { Jericho [R 17], } \\
\text { fol. LXXXIIIv }\end{array}$ & $\begin{array}{l}\text { Healing of the } \\
\text { blind man of } \\
\text { Jericho [H } \\
\text { 1019], fol. } \\
\text { LXXXVIIv }\end{array}$ \\
\hline $\begin{array}{l}\text { 1st Sunday of } \\
\text { Lent }\end{array}$ & Mt 4: 1-11 & $\begin{array}{l}\text { Temptation of } \\
\text { Christ [S 17], } \\
\text { fol. LXIXv }\end{array}$ & $\begin{array}{l}\text { Temptation of } \\
\text { Christ [R 18], } \\
\text { fol. LXXXVII }\end{array}$ & $\begin{array}{l}\text { Temptation of } \\
\text { Christ [R 19], } \\
\text { fol. LXXXVII }\end{array}$ & $\begin{array}{l}\text { Temptation of } \\
\text { Christ [H 1020], } \\
\text { fol. XCI }\end{array}$ \\
\hline $\begin{array}{l}\text { 2nd Sunday of } \\
\text { Lent }\end{array}$ & Mt 15: 21-28 & $\begin{array}{l}\text { Christ and the } \\
\text { Canaanite } \\
\text { woman [S 18], } \\
\text { fol. LXXIIv }\end{array}$ & $\begin{array}{l}\text { Christ and the } \\
\text { Canaanite } \\
\text { woman [R 19], } \\
\text { fol. XCV }\end{array}$ & $\begin{array}{l}\text { Christ and the } \\
\text { Canaanite } \\
\text { woman [R 19], } \\
\text { fol. XCV }\end{array}$ & $\begin{array}{l}\text { Christ and the } \\
\text { Canaanite } \\
\text { woman [H } \\
\text { 1021], fol. XCV }\end{array}$ \\
\hline $\begin{array}{l}\text { 3rd Sunday of } \\
\text { Lent }\end{array}$ & Lk 11: 14-28 & $\begin{array}{l}\text { Christ healing a } \\
\text { demoniac [S } \\
\text { 19], fol. } \\
\text { LXXIVv }\end{array}$ & $\begin{array}{l}\text { Christ healing a } \\
\text { demoniac [R } \\
\text { 20], fol. XCIIIv }\end{array}$ & $\begin{array}{l}\text { Christ healing a } \\
\text { demoniac [R } \\
\text { 20], fol. XCIIIv }\end{array}$ & $\begin{array}{l}\text { Christ healing a } \\
\text { demoniac [H } \\
\text { 1022], fol. } \\
\text { XCVIII }\end{array}$ \\
\hline
\end{tabular}




\begin{tabular}{|c|c|c|c|c|c|}
\hline Feast & Pericope & Luther 1544b & Luther 1545a & Luther 1548 & Luther 1549 \\
\hline $\begin{array}{l}\text { 4th Sunday of } \\
\text { Lent }\end{array}$ & J 6: 1-15 & $\begin{array}{l}\text { Feeding the } \\
\text { multitude [S } \\
\text { 20], fol. } \\
\text { LXXVIIIv }\end{array}$ & $\begin{array}{l}\text { Feeding the } \\
\text { multitude [R } \\
21], \text { fol. } \\
\text { XCVIIIv }\end{array}$ & $\begin{array}{l}\text { Feeding the } \\
\text { multitude [R } \\
21], \text { fol. } \\
\text { XCVIIIv }\end{array}$ & $\begin{array}{l}\text { Feeding the } \\
\text { multitude [H } \\
\text { 1023], fol. CIII }\end{array}$ \\
\hline $\begin{array}{l}\text { 5th Sunday of } \\
\text { Lent }\end{array}$ & J 8: 46-59 & $\begin{array}{l}\text { Christ and the } \\
\text { Pharisees } \\
\text { (taxes) [S 21], } \\
\text { fol. LXXXII }\end{array}$ & $\begin{array}{l}\text { Christ and the } \\
\text { Pharisees [R } \\
\text { 22], fol. CIIv }\end{array}$ & $\begin{array}{l}\text { Christ and the } \\
\text { Pharisees [R } \\
\text { 22], fol. CIIv }\end{array}$ & $\begin{array}{l}\text { Attempt to } \\
\text { stone Christ [H } \\
\text { 1024], fol. } \\
\text { CVIIv }\end{array}$ \\
\hline Palm Sunday & 1Cor 11: $23-26^{1}$ & $\begin{array}{l}\text { Comunion and } \\
\text { procession [S } \\
\text { 22], fol. } \\
\text { LXXXIVv }\end{array}$ & $\begin{array}{l}\text { Comunion and } \\
\text { procession [S } \\
\text { 22], fol. CVI }\end{array}$ & $\begin{array}{l}\text { Comunion and } \\
\text { procession [S } \\
22 \text {; state II], fol. } \\
\text { CVI }\end{array}$ & $\begin{array}{l}\text { Comunion and } \\
\text { procession [S } \\
\text { 22, state II], fol. } \\
\text { CXI }\end{array}$ \\
\hline $\begin{array}{l}\text { Maundy } \\
\text { Thursday }\end{array}$ & J 13: 1-17 & $\begin{array}{l}\text { Christ washing } \\
\text { the feet of the } \\
\text { disciples [S 23], } \\
\text { fol. LXXXIXv }\end{array}$ & $\begin{array}{l}\text { Christ washing } \\
\text { the feet of the } \\
\text { disciples [S 23], } \\
\text { fol. CXII }\end{array}$ & $\begin{array}{l}\text { Christ washing } \\
\text { the feet of the } \\
\text { disciples [S 23], } \\
\text { fol. CXII }\end{array}$ & $\begin{array}{l}\text { Christ washing } \\
\text { the feet of the } \\
\text { disciples [S 23], } \\
\text { fol. CXVII }\end{array}$ \\
\hline \multicolumn{6}{|c|}{ Passion } \\
\hline 1st Sermon & Lk 23: 32-43 & $\begin{array}{l}\text { Crucifixion } \\
\text { (after Cranach), } \\
\text { fol. XCVIIIv }\end{array}$ & $\begin{array}{l}\text { Agony in the } \\
\text { garden [R 23], } \\
\text { fol. CXXIII }\end{array}$ & $\begin{array}{l}\text { Agony in the } \\
\text { garden [R 23], } \\
\text { fol. CXXIII }\end{array}$ & $\begin{array}{l}\text { Agony in the } \\
\text { garden [R 23], } \\
\text { fol. CXXVIII }\end{array}$ \\
\hline 3rd Sermon & & & $\begin{array}{l}\text { Arrest of Christ } \\
\text { [R 24], fol. } \\
\text { CXXXIv }\end{array}$ & $\begin{array}{l}\text { Arrest of Christ } \\
\text { [R 24], fol. } \\
\text { CXXXIv }\end{array}$ & $\begin{array}{l}\text { Arrest of Christ } \\
\text { [R 24], fol. } \\
\text { CXXXVIv }\end{array}$ \\
\hline 4th Sermon & & & $\begin{array}{l}\text { Christ before } \\
\text { Caiphas [R 25], } \\
\text { fol. CXXXV }\end{array}$ & $\begin{array}{l}\text { Christ before } \\
\text { Caiphas [R 25], } \\
\text { fol. CXXXV }\end{array}$ & $\begin{array}{l}\text { Christ before } \\
\text { Caiphas [R 25], } \\
\text { fol. CXLv }\end{array}$ \\
\hline 6th Sermon & & & $\begin{array}{l}\text { Christ before } \\
\text { Pilate [R 26], } \\
\text { fol. CXLI }\end{array}$ & $\begin{array}{l}\text { Christ before } \\
\text { Pilate [R 26], } \\
\text { fol. CXLI }\end{array}$ & $\begin{array}{l}\text { Christ before } \\
\text { Pilate [R 26], } \\
\text { fol. CXLVIv }\end{array}$ \\
\hline 9th Sermon & & & $\begin{array}{l}\text { Christ carrying } \\
\text { the cross [R 27], } \\
\text { fol. CLIIv }\end{array}$ & $\begin{array}{l}\text { Christ carrying } \\
\text { the cross [R 27], } \\
\text { fol. CLIIv }\end{array}$ & $\begin{array}{l}\text { Christ carrying } \\
\text { the cross [R 27], } \\
\text { fol. CLVIII }\end{array}$ \\
\hline 10th Sermon & & & $\begin{array}{l}\text { Christ nailed to } \\
\text { the cross [R 28], } \\
\text { fol. CLVIv }\end{array}$ & $\begin{array}{l}\text { Crucifixion [R } \\
\text { 29], fol. CLVIv }\end{array}$ & $\begin{array}{l}\text { Crucifixion [R } \\
\text { 29], fol. CLXII }\end{array}$ \\
\hline 11th Sermon & & & $\begin{array}{l}\text { Crucifixion [R } \\
\text { 29], fol. CLXIv }\end{array}$ & $\begin{array}{l}\text { Crucifixion [R } \\
\text { 29], fol. CLXIv }\end{array}$ & $\begin{array}{l}\text { Crucifixion [R } \\
\text { 29], fol. CLXVII }\end{array}$ \\
\hline 13th Sermon & & & & & $\begin{array}{l}\text { Lamentation [R } \\
\text { 30], fol. } \\
\text { CLXVIV }\end{array}$ \\
\hline \multicolumn{6}{|c|}{ Summer postil } \\
\hline \multirow{3}{*}{ Easter Sunday } & Mt 28: 1-9 & $\begin{array}{l}\text { The three } \\
\text { Maries at the } \\
\text { tomb [S 24], fol. } \\
\text { CII }\end{array}$ & $\begin{array}{l}\text { Risen Christ [R } \\
\text { 31], fol. II }\end{array}$ & $\begin{array}{l}\text { Risen Christ [R } \\
\text { 31], fol. II }\end{array}$ & $\begin{array}{l}\text { The three } \\
\text { Maries at the } \\
\text { tomb [H 1026], } \\
\text { fol. II }\end{array}$ \\
\hline & & & & $\begin{array}{l}\text { The three } \\
\text { Maries at the } \\
\text { tomb [R 32], fol. } \\
\text { VI }\end{array}$ & $\begin{array}{l}\text { Christ } \\
\text { appearing on } \\
\text { the road to } \\
\text { Emmaus [H } \\
\text { 1027], fol. VI }\end{array}$ \\
\hline & Lk 24: 13-35 & & & & $\begin{array}{l}\text { Risen Christ } \\
\text { appearing to } \\
\text { the Apostles [H } \\
\text { 1028], fol. IXv }\end{array}$ \\
\hline
\end{tabular}




\begin{tabular}{|c|c|c|c|c|c|}
\hline Feast & Pericope & Luther $1544 b$ & Luther 1545a & Luther 1548 & Luther 1549 \\
\hline $\begin{array}{l}\text { 1st Sunday } \\
\text { after Easter }\end{array}$ & J 20: 19-31 & $\begin{array}{l}\text { Incredulity of } \\
\text { Thomas [S 25], } \\
\text { fol. XXVII }\end{array}$ & $\begin{array}{l}\text { Incredulity of } \\
\text { Thomas [S 25], } \\
\text { fol. CXI }\end{array}$ & $\begin{array}{l}\text { Incredulity of } \\
\text { Thomas [R 33], } \\
\text { fol. XII }\end{array}$ & $\begin{array}{l}\text { Incredulity of } \\
\text { Thomas [H } \\
\text { 1029], fol. XIIIv }\end{array}$ \\
\hline $\begin{array}{l}\text { 2nd Sunday } \\
\text { after Easter }\end{array}$ & J 10: 11-16 & $\begin{array}{l}\text { Parable of the } \\
\text { good Shepherd } \\
\text { [S 26], fol. CXV }\end{array}$ & $\begin{array}{l}\text { Parable of the } \\
\text { good Shepherd } \\
\text { [R 34], fol. } \\
\text { XVIII }\end{array}$ & $\begin{array}{l}\text { Parable of the } \\
\text { good Shepherd } \\
\text { [R 34], fol. XVII }\end{array}$ & $\begin{array}{l}\text { Parable of the } \\
\text { good shepherd } \\
\text { [H 1030], fol. } \\
\text { XVIIIv }\end{array}$ \\
\hline $\begin{array}{l}\text { 3rd Sunday } \\
\text { after Easter }\end{array}$ & J 16: 16-23 & $\begin{array}{l}\text { Christ with } \\
\text { disciples [S 27], } \\
\text { fol. CXVIII }\end{array}$ & $\begin{array}{l}\text { Christ with } \\
\text { disciples [R 35], } \\
\text { fol. XXII }\end{array}$ & $\begin{array}{l}\text { Christ with } \\
\text { disciples [R 35], } \\
\text { fol. XXII }\end{array}$ & $\begin{array}{l}\text { Christ with } \\
\text { disciples [H } \\
\text { 1031], fol. } \\
\text { XXIIv }\end{array}$ \\
\hline $\begin{array}{l}\text { 4th Sunday } \\
\text { after Easter }\end{array}$ & J 16: 5-15 & $\begin{array}{l}\text { Christ with } \\
\text { disciples [S 28], } \\
\text { fol. CXXI }\end{array}$ & $\begin{array}{l}\text { Christ with } \\
\text { disciples [R 36], } \\
\text { fol. XXVV }\end{array}$ & $\begin{array}{l}\text { Christ with } \\
\text { disciples [R 36], } \\
\text { fol. XXIX }\end{array}$ & $\begin{array}{l}\text { Christ with } \\
\text { disciples [H } \\
\text { 1032], fol. XXX }\end{array}$ \\
\hline $\begin{array}{l}\text { 5th Sunday } \\
\text { after Easter }\end{array}$ & J 16: 23-30 & $\begin{array}{l}\text { Christ with } \\
\text { disciples [S 29], } \\
\text { fol. CXXV }\end{array}$ & $\begin{array}{l}\text { Christ with } \\
\text { disciples [R 37], } \\
\text { fol. XXX }\end{array}$ & $\begin{array}{l}\text { Christ with } \\
\text { disciples [R 37], } \\
\text { fol. XXXIIIv }\end{array}$ & $\begin{array}{l}\text { Christ } \\
\text { preaching [H } \\
\text { 1033], fol. } \\
\text { XXXV }\end{array}$ \\
\hline Ascension & Mt 16: 14-20 & $\begin{array}{l}\text { Ascension [S } \\
\text { 30], fol. } \\
\text { CXX[VIII] }\end{array}$ & $\begin{array}{l}\text { Ascension [R } \\
\text { 38], fol. } \\
\text { XXXIIIv }\end{array}$ & $\begin{array}{l}\text { Ascension [R } \\
\text { 38], fol. } \\
\text { XXXVIIv }\end{array}$ & $\begin{array}{l}\text { Ascension [H } \\
\text { 1034], fol. } \\
\text { XXXIX }\end{array}$ \\
\hline $\begin{array}{l}\text { 6th Sunday } \\
\text { after Easter }\end{array}$ & J 15: 26-16,4 & $\begin{array}{l}\text { Christ with } \\
\text { disciples [S 27], } \\
\text { fol. CXXXIv }\end{array}$ & $\begin{array}{l}\text { Christ with } \\
\text { disciples [R 36], } \\
\text { fol. XXXVIIv }\end{array}$ & $\begin{array}{l}\text { Christ with } \\
\text { disciples [R 36], } \\
\text { fol. XLI }\end{array}$ & $\begin{array}{l}\text { Christ with } \\
\text { disciples [H } \\
\text { 1035], fol. XLIII }\end{array}$ \\
\hline $\begin{array}{l}\text { Pentecost } \\
\text { Sunday }\end{array}$ & J 14: 21-31 & $\begin{array}{l}\text { Pentecost [S 31], } \\
\text { fol. CXXXV }\end{array}$ & $\begin{array}{l}\text { Pentecost [R } \\
\text { 39], fol. XLIv }\end{array}$ & $\begin{array}{l}\text { Pentecost [R } \\
\text { 39], fol. XLV }\end{array}$ & $\begin{array}{l}\text { Pentecost [H } \\
\text { 1036], fol. } \\
\text { XLVII }\end{array}$ \\
\hline $\begin{array}{l}\text { Pentecost } \\
\text { Monday }\end{array}$ & J 3: 16-21 & $\begin{array}{l}\text { Crucifixion, fol. } \\
\text { CXL }\end{array}$ & $\begin{array}{l}\text { Crucifixion [R } \\
\text { 29], fol. XLVIIv }\end{array}$ & $\begin{array}{l}\text { Crucifixion [R } \\
\text { 29], fol. Liv }\end{array}$ & $\begin{array}{l}\text { Christ talking } \\
\text { to Nicodemus } \\
\text { [H 1037], fol. } \\
\text { LIIIv }\end{array}$ \\
\hline Holy Trinity & J 3: 1-14 & $\begin{array}{l}\text { Holy Trinity } \\
\text { (Creation of } \\
\text { Adam, } \\
\text { Crucifix and } \\
\text { Pentecost) [S } \\
\text { 32], fol. CXLIV }\end{array}$ & $\begin{array}{l}\text { Holy Trinity } \\
\text { (Creation of } \\
\text { Adam, } \\
\text { Crucifix and } \\
\text { Pentecost) [S } \\
\text { 32], fol. LII }\end{array}$ & $\begin{array}{l}\text { Holy Trinity } \\
\text { (Creation of } \\
\text { Adam, } \\
\text { Crucifix and } \\
\text { Pentecost) [S } \\
\text { 32], fol. LVI }\end{array}$ & $\begin{array}{l}\text { Christ talking } \\
\text { to Nicodemus } \\
\text { and St John } \\
\text { baptizing [H } \\
\text { 1039], fol. LVIII }\end{array}$ \\
\hline Holy Trinity & & $\begin{array}{l}\text { Christ talking } \\
\text { to Nicodemus } \\
\text { [S 33], fol. } \\
\text { CXLVIIIv }\end{array}$ & $\begin{array}{l}\text { Christ talking } \\
\text { to Nicodemus } \\
\text { [R 40], fol. LVII }\end{array}$ & $\begin{array}{l}\text { Christ talking } \\
\text { to Nicodemus } \\
\text { [R 40], fol. LXI }\end{array}$ & $\begin{array}{l}\text { Christ talking } \\
\text { to Nicodemus } \\
\text { and St John } \\
\text { baptizing [H } \\
\text { 1039], fol. } \\
\text { LXIIIv }\end{array}$ \\
\hline $\begin{array}{l}\text { 1st Sunday } \\
\text { after Trinity }\end{array}$ & Lk 14: 16-24 & $\begin{array}{l}\text { Parable of the } \\
\text { great banquet } \\
\text { [S 34], fol. CLIII }\end{array}$ & $\begin{array}{l}\text { Parable of the } \\
\text { great banquet } \\
\text { [R 41], fol. } \\
\text { LXIIv }\end{array}$ & $\begin{array}{l}\text { Parable of the } \\
\text { great banquet } \\
\text { [R 41], fol. } \\
\text { LXVIIv }\end{array}$ & $\begin{array}{l}\text { Parable of the } \\
\text { great banquet } \\
\text { [H 1041], fol. } \\
\text { LXIX }\end{array}$ \\
\hline $\begin{array}{l}\text { 2nd Sunday } \\
\text { after Trinity }\end{array}$ & Lk 16: 19-31 & $\begin{array}{l}\text { Parable of } \\
\text { Lazarus and } \\
\text { the rich man [S } \\
\text { 35], fol. CLVIII }\end{array}$ & $\begin{array}{l}\text { Parable of } \\
\text { Lazarus and } \\
\text { the rich man [R } \\
42], \text { fol. } \\
\text { LXXXVIv }\end{array}$ & $\begin{array}{l}\text { Parable of } \\
\text { Lazarus and } \\
\text { the rich man [R } \\
42] \text {, fol. LXXIII }\end{array}$ & $\begin{array}{l}\text { Parable of } \\
\text { Lazarus and } \\
\text { the rich man [H } \\
\text { 1040], fol. } \\
\text { LXXVv }\end{array}$ \\
\hline
\end{tabular}




\begin{tabular}{|c|c|c|c|c|c|}
\hline Feast & Pericope & Luther $1544 b$ & Luther 1545a & Luther 1548 & Luther 1549 \\
\hline $\begin{array}{l}\text { 3rd Sunday } \\
\text { after Trinity }\end{array}$ & Lk 15: 1-10 & $\begin{array}{l}\text { Parable of the } \\
\text { lost sheep [S } \\
\text { 36], fol. CLXIv }\end{array}$ & $\begin{array}{l}\text { Parable of the } \\
\text { lost sheep [R } \\
43], \text { fol. LXXIIv }\end{array}$ & $\begin{array}{l}\text { Healing a } \\
\text { paralytic [R 57], } \\
\text { fol. LXXVIIv }\end{array}$ & $\begin{array}{l}\text { Parable of the } \\
\text { lost sheep [H } \\
\text { 1042], fol. } \\
\text { LXXX }\end{array}$ \\
\hline $\begin{array}{l}\text { 4th Sunday } \\
\text { after Trinity }\end{array}$ & Lk 6: 36-42 & $\begin{array}{l}\text { The parable of } \\
\text { the speck and } \\
\text { the log [S 37], } \\
\text { fol. CLXV }\end{array}$ & $\begin{array}{l}\text { The parable of } \\
\text { the speck and } \\
\text { the log [R } 44] \text {, } \\
\text { fol. LXXVI }\end{array}$ & $\begin{array}{l}\text { The parable of } \\
\text { the speck and } \\
\text { the log [R 44], } \\
\text { fol. LXXXI }\end{array}$ & $\begin{array}{l}\text { The parable of } \\
\text { the speck and } \\
\text { the log [H } \\
\text { 1043], fol. } \\
\text { LXXXIV }\end{array}$ \\
\hline $\begin{array}{l}\text { 5th Sunday } \\
\text { after Trinity }\end{array}$ & Lk 5: 1-11 & $\begin{array}{l}\text { Christ } \\
\text { preaching in a } \\
\text { ship [S 38], fol. } \\
\text { CLXIXv }\end{array}$ & $\begin{array}{l}\text { Christ } \\
\text { preaching in a } \\
\text { ship [R 45], fol. } \\
\text { LXXXIv }\end{array}$ & $\begin{array}{l}\text { Christ } \\
\text { preaching in a } \\
\text { ship [R 45], fol. } \\
\text { LXXXVIv }\end{array}$ & $\begin{array}{l}\text { Christ } \\
\text { preaching in a } \\
\text { ship [H 1044], } \\
\text { fol. XC }\end{array}$ \\
\hline $\begin{array}{l}\text { 6th Sunday } \\
\text { after Trinity }\end{array}$ & Mt 5: 20-26 & $\begin{array}{l}\text { Christ } \\
\text { preaching [S } \\
\text { 39], fol. } \\
\text { CLXXIIIv }\end{array}$ & $\begin{array}{l}\text { Christ } \\
\text { preaching [R } \\
\text { 46], fol. } \\
\text { LXXXVIv }\end{array}$ & $\begin{array}{l}\text { Christ } \\
\text { preaching [R } \\
46], \text { fol. XCIv }\end{array}$ & $\begin{array}{l}\text { Christ } \\
\text { preaching [H } \\
\text { 1045], fol. CXV }\end{array}$ \\
\hline $\begin{array}{l}\text { 7th Sunday } \\
\text { after Trinity }\end{array}$ & Mt 8: 1-9 & $\begin{array}{l}\text { Feeding the } \\
\text { multitude [S } \\
40], \text { fol. } \\
\text { CLXXVII }\end{array}$ & $\begin{array}{l}\text { Feeding the } \\
\text { multitude [R } \\
\text { 21], fol. XCV }\end{array}$ & $\begin{array}{l}\text { Feeding the } \\
\text { multitude [R } \\
\text { 21], fol. XCV }\end{array}$ & $\begin{array}{l}\text { Feeding the } \\
\text { multitude [H } \\
\text { 1046], fol. } \\
\text { XCXIXv }\end{array}$ \\
\hline $\begin{array}{l}\text { 8th Sunday } \\
\text { after Trinity }\end{array}$ & Mt 7: 15-23 & $\begin{array}{l}\text { Warning } \\
\text { against false } \\
\text { prophets [S 41], } \\
\text { fol. CLXXX }\end{array}$ & $\begin{array}{l}\text { Warning } \\
\text { against false } \\
\text { prophets [S 41], } \\
\text { fol. XCIVv }\end{array}$ & $\begin{array}{l}\text { Christ with } \\
\text { disciples [R 34], } \\
\text { fol. XCIXv }\end{array}$ & $\begin{array}{l}\text { Warning } \\
\text { against false } \\
\text { prophets [H } \\
\text { 1047], fol. CIIIv }\end{array}$ \\
\hline $\begin{array}{l}\text { 9th Sunday } \\
\text { after Trinity }\end{array}$ & Lk 16: 1-9 & $\begin{array}{l}\text { Parable of the } \\
\text { unjust steward } \\
\text { [S 42], fol. } \\
\text { CLXXXIIIv }\end{array}$ & $\begin{array}{l}\text { Parable of the } \\
\text { unjust steward } \\
\text { [R 47], fol. } \\
\text { XCIX }\end{array}$ & $\begin{array}{l}\text { Parable of the } \\
\text { unjust steward } \\
\text { [R 47], fol. CIV }\end{array}$ & $\begin{array}{l}\text { Parable of the } \\
\text { unjust steward } \\
\text { [H 1048], fol. } \\
\text { CVIII }\end{array}$ \\
\hline $\begin{array}{l}\text { 10th Sunday } \\
\text { after Trinity }\end{array}$ & Lk 19: 41-48 & $\begin{array}{l}\text { Cleansing of } \\
\text { the temple [S } \\
\text { 43], fol. } \\
\text { CXXXVIv }\end{array}$ & $\begin{array}{l}\text { Siege of the } \\
\text { church [R 48], } \\
\text { fol. CIII }\end{array}$ & $\begin{array}{l}\text { Siege of the } \\
\text { church [R 48], } \\
\text { fol. CVIII }\end{array}$ & $\begin{array}{l}\text { Cleansing of } \\
\text { the temple [H } \\
\text { 1049], fol. } \\
\text { CXIIv }\end{array}$ \\
\hline $\begin{array}{l}\text { 11th Sunday } \\
\text { after Trinity }\end{array}$ & Lk 18: 9-14 & $\begin{array}{l}\text { Parable of the } \\
\text { Pharisee and } \\
\text { the tax collector } \\
\text { [S 44], fol. } \\
\text { CXCv }\end{array}$ & $\begin{array}{l}\text { Parable of the } \\
\text { Pharisee and } \\
\text { the tax collector } \\
\text { [R 49], fol. } \\
\text { CVIII }\end{array}$ & $\begin{array}{l}\text { Parable of the } \\
\text { Pharisee and } \\
\text { the tax collector } \\
\text { [R 49], fol. } \\
\text { CXIII }\end{array}$ & $\begin{array}{l}\text { Parable of the } \\
\text { Pharisee and } \\
\text { the tax collector } \\
\text { [H 1050], fol. } \\
\text { CXVIIv }\end{array}$ \\
\hline $\begin{array}{l}\text { 12th Sunday } \\
\text { after Trinity }\end{array}$ & Mt 7: 31-37 & $\begin{array}{l}\text { Healing of a } \\
\text { deaf and dumb } \\
\text { man [S 45], fol. } \\
\text { CXCIII }\end{array}$ & $\begin{array}{l}\text { Healing of a } \\
\text { deaf and dumb } \\
\text { man [R 50], fol. } \\
\text { CXI }\end{array}$ & $\begin{array}{l}\text { Healing of a } \\
\text { deaf and dumb } \\
\text { man [R 50], fol. } \\
\text { CXVI }\end{array}$ & $\begin{array}{l}\text { Healing of a } \\
\text { deaf and dumb } \\
\text { man [H 1051], } \\
\text { fol. CXXI }\end{array}$ \\
\hline $\begin{array}{l}\text { 13th Sunday } \\
\text { after Trinity }\end{array}$ & Lk 10: 22-37 & $\begin{array}{l}\text { Parable of the } \\
\text { good Samaritan } \\
\text { [S 46], fol. } \\
\text { CXCVv }\end{array}$ & $\begin{array}{l}\text { Parable of the } \\
\text { good Samaritan } \\
\text { [R 51], fol. } \\
\text { CXIV }\end{array}$ & $\begin{array}{l}\text { Parable of the } \\
\text { good Samaritan } \\
\text { [R 51], fol. } \\
\text { CXIX }\end{array}$ & $\begin{array}{l}\text { Parable of the } \\
\text { good Samaritan } \\
\text { [H 1052], fol. } \\
\text { CXXIV }\end{array}$ \\
\hline $\begin{array}{l}\text { 14th Sunday } \\
\text { after Trinity }\end{array}$ & Lk 17: 11-19 & $\begin{array}{l}\text { Healing the ten } \\
\text { lepers [S 47], } \\
\text { fol. CXCIX }\end{array}$ & $\begin{array}{l}\text { Healing a leper } \\
\text { [R 52], fol. } \\
\text { CXIXv }\end{array}$ & $\begin{array}{l}\text { Healing a leper } \\
\text { [R 52], fol. } \\
\text { CXXIVv }\end{array}$ & $\begin{array}{l}\text { Healing the ten } \\
\text { lepers [H 1053], } \\
\text { fol. CXXIXv }\end{array}$ \\
\hline
\end{tabular}




\begin{tabular}{|c|c|c|c|c|c|}
\hline Feast & Pericope & Luther 1544b & Luther 1545a & Luther 1548 & Luther 1549 \\
\hline $\begin{array}{l}\text { 15th Sunday } \\
\text { after Trinity }\end{array}$ & Mt 6: 24-34 & $\begin{array}{l}\text { Earthly versus } \\
\text { heavenly } \\
\text { treasures [S 48], } \\
\text { fol. CCIv }\end{array}$ & $\begin{array}{l}\text { Earthly versus } \\
\text { heavenly } \\
\text { treasures [R 53], } \\
\text { fol. CXXIIv }\end{array}$ & $\begin{array}{l}\text { Earthly versus } \\
\text { heavenly } \\
\text { treasures [R 53], } \\
\text { fol. CXXVIIv }\end{array}$ & $\begin{array}{l}\text { Earthly versus } \\
\text { heavenly } \\
\text { treasures [H } \\
\text { 1054], fol. } \\
\text { CXXXIII }\end{array}$ \\
\hline $\begin{array}{l}\text { 16th Sunday } \\
\text { after Trinity }\end{array}$ & Lk 7: 11-17 & $\begin{array}{l}\text { Raising of the } \\
\text { son of a widow } \\
\text { in Nain [S 49], } \\
\text { fol. CCVV }\end{array}$ & $\begin{array}{l}\text { Raising of the } \\
\text { son of a widow } \\
\text { in Nain [R 54], } \\
\text { fol. CXXVIIv }\end{array}$ & $\begin{array}{l}\text { Raising of the } \\
\text { son of a widow } \\
\text { in Nain [R 54], } \\
\text { fol. CXXXIIv }\end{array}$ & $\begin{array}{l}\text { Raising of the } \\
\text { son of a widow } \\
\text { in Nain [H } \\
\text { 1055], fol. } \\
\text { CXXXVIIIv }\end{array}$ \\
\hline $\begin{array}{l}\text { 17th Sunday } \\
\text { after Trinity }\end{array}$ & Lk 14: 1-11 & $\begin{array}{l}\text { Healing a sick } \\
\text { man on the } \\
\text { Sabbath [S 50], } \\
\text { fol. CCVIIIv }\end{array}$ & $\begin{array}{l}\text { Healing a sick } \\
\text { man on the } \\
\text { Sabbath [R 55], } \\
\text { fol. CXXXv }\end{array}$ & $\begin{array}{l}\text { Healing a sick } \\
\text { man on the } \\
\text { Sabbath [R 55], } \\
\text { fol. CXXXVv }\end{array}$ & $\begin{array}{l}\text { Healing a sick } \\
\text { man on the } \\
\text { Sabbath [H } \\
\text { 1056], fol. } \\
\text { CXIIv }\end{array}$ \\
\hline $\begin{array}{l}\text { 18th Sunday } \\
\text { after Trinity }\end{array}$ & Mt 22: 34-46 & $\begin{array}{l}\text { Christ and the } \\
\text { Pharisees [S 51], } \\
\text { fol. CCXv }\end{array}$ & $\begin{array}{l}\text { Christ and the } \\
\text { Pharisees [R } \\
\text { 56], fol. } \\
\text { CXXXIIIv }\end{array}$ & $\begin{array}{l}\text { Christ and the } \\
\text { Pharisees [R } \\
\text { 56], fol. } \\
\text { CXXXVIIIv }\end{array}$ & $\begin{array}{l}\text { Christ and the } \\
\text { Pharisees (The } \\
\text { tribute to be } \\
\text { paid to Caesar) } \\
\text { [H 1057], fol. } \\
\text { CXLIVv }\end{array}$ \\
\hline $\begin{array}{l}\text { 19th Sunday } \\
\text { after Trinity }\end{array}$ & Mt 9: 1-8 & $\begin{array}{l}\text { Healing a } \\
\text { paralytic [S 49], } \\
\text { fol. CCXIV }\end{array}$ & $\begin{array}{l}\text { Healing a } \\
\text { paralytic [R 57], } \\
\text { fol. CXXXVIIv }\end{array}$ & $\begin{array}{l}\text { Healing a } \\
\text { paralytic [R 57], } \\
\text { fol. CXLIII }\end{array}$ & $\begin{array}{l}\text { Healing a } \\
\text { paralytic [H } \\
\text { 1058], fol. } \\
\text { CXLIX }\end{array}$ \\
\hline $\begin{array}{l}\text { 20th Sunday } \\
\text { after Trinity }\end{array}$ & Mt 22: 1-14 & $\begin{array}{l}\text { Parable of the } \\
\text { wedding } \\
\text { banquet [S 52], } \\
\text { fol. CCXVIIv }\end{array}$ & $\begin{array}{l}\text { Parable of the } \\
\text { wedding } \\
\text { banquet [R 58], } \\
\text { fol. CXLIv }\end{array}$ & $\begin{array}{l}\text { Parable of the } \\
\text { wedding } \\
\text { banquet [R 58], } \\
\text { fol. CXLVII }\end{array}$ & $\begin{array}{l}\text { Parable of the } \\
\text { wedding } \\
\text { banquet [H } \\
\text { 1059], fol. } \\
\text { CLIIIv }\end{array}$ \\
\hline $\begin{array}{l}\text { 21th Sunday } \\
\text { after Trinity }\end{array}$ & J 4: 46-54 & $\begin{array}{l}\text { Healing of an } \\
\text { official's son [S } \\
\text { 53], fol. } \\
\text { CCXXIv }\end{array}$ & $\begin{array}{l}\text { Healing of an } \\
\text { official's son [R } \\
50], \text { fol. } \\
\text { CXLVIv }\end{array}$ & $\begin{array}{l}\text { Healing of an } \\
\text { official's son [R } \\
\text { 59], fol. CLIIv }\end{array}$ & $\begin{array}{l}\text { Healing of an } \\
\text { official's son [H } \\
\text { 1060], fol. CLIX }\end{array}$ \\
\hline $\begin{array}{l}\text { 22th Sunday } \\
\text { after Trinity }\end{array}$ & Mt 18: 23-35 & $\begin{array}{l}\text { Parable of the } \\
\text { unmerciful } \\
\text { servant [S 54], } \\
\text { fol. CCXXIVv }\end{array}$ & $\begin{array}{l}\text { Parable of the } \\
\text { unmerciful } \\
\text { servant [R 60], } \\
\text { fol. CLv }\end{array}$ & $\begin{array}{l}\text { Parable of the } \\
\text { unmerciful } \\
\text { servant [R 60], } \\
\text { fol. CLVI }\end{array}$ & $\begin{array}{l}\text { Parable of the } \\
\text { unmerciful } \\
\text { servant [H } \\
\text { 1061], fol. } \\
\text { CLXIII }\end{array}$ \\
\hline $\begin{array}{l}\text { 23th Sunday } \\
\text { after Trinity }\end{array}$ & Mt 22: 15-22 & $\begin{array}{l}\text { Christ and the } \\
\text { Pharisees [S 21], } \\
\text { fol. CCXXVIII }\end{array}$ & $\begin{array}{l}\text { Christ and the } \\
\text { Pharisees [R } \\
\text { 22], fol. CLIVv }\end{array}$ & $\begin{array}{l}\text { Christ and the } \\
\text { Pharisees [R } \\
\text { 22], fol. CLXv }\end{array}$ & $\begin{array}{l}\text { Christ and the } \\
\text { Pharisees (The } \\
\text { tribute to be } \\
\text { paid to Caesar) } \\
\text { [H 1057], fol. } \\
\text { CLXVIIv }\end{array}$ \\
\hline $\begin{array}{l}\text { 24th Sunday } \\
\text { after Trinity }\end{array}$ & Mt 9: 18-26 & $\begin{array}{l}\text { Healing the } \\
\text { bleeding } \\
\text { woman [S 55], } \\
\text { fol. CCXXXIv }\end{array}$ & $\begin{array}{l}\text { Healing the } \\
\text { bleeding } \\
\text { woman and } \\
\text { Jair's daughter } \\
\text { [R 61], fol. } \\
\text { CLIX }\end{array}$ & $\begin{array}{l}\text { Healing the } \\
\text { bleeding } \\
\text { woman and } \\
\text { Jair's daughter } \\
\text { [R 61], fol. } \\
\text { CLXIVv }\end{array}$ & $\begin{array}{l}\text { Healing the } \\
\text { bleeding } \\
\text { woman and } \\
\text { Jair's daughter } \\
\text { [H 1062], fol. } \\
\text { CLXXII }\end{array}$ \\
\hline
\end{tabular}




\begin{tabular}{|c|c|c|c|c|c|}
\hline Feast & Pericope & Luther $1544 b$ & Luther 1545a & Luther 1548 & Luther 1549 \\
\hline $\begin{array}{l}\text { 25th Sunday } \\
\text { after Trinity }\end{array}$ & Mt 24: 15-28 & $\begin{array}{l}\text { Christ with } \\
\text { disciples [S 28], } \\
\text { fol. CCXXXV }\end{array}$ & $\begin{array}{l}\text { Christ with } \\
\text { disciples [R 35], } \\
\text { fol. CLXIII }\end{array}$ & $\begin{array}{l}\text { Christ with } \\
\text { disciples [R 35], } \\
\text { fol. CLXIX }\end{array}$ & $\begin{array}{l}\text { Christ } \\
\text { foretelling the } \\
\text { destruction of } \\
\text { the Temple [H } \\
\text { 1063], fol. } \\
\text { CLXXVIv }\end{array}$ \\
\hline $\begin{array}{l}\text { 26th Sunday } \\
\text { after Trinity }\end{array}$ & [J 6: $1-15]^{2}$ & $\begin{array}{l}\text { [fol. } \\
\text { CCXXXVIIIv; } \\
\text { ref. to 4th } \\
\text { Sunday of Lent] }\end{array}$ & $\begin{array}{l}\text { [fol. CLXVIIv, } \\
\text { ref. to } 4 \text { th } \\
\text { Sunday of Lent] }\end{array}$ & $\begin{array}{l}\text { [fol. CLXXIIIv, } \\
\text { ref. to } 4 \text { th } \\
\text { Sunday of Lent] }\end{array}$ & $\begin{array}{l}\text { [fol. CLXXXI, } \\
\text { ref. to } 4 \text { th } \\
\text { Sunday of Lent] }\end{array}$ \\
\hline $\begin{array}{l}\text { 27th Sunday } \\
\text { after Trinity }\end{array}$ & Mt 5: 1-12 & $\begin{array}{l}\text { Sermon on the } \\
\text { mount [S 56], } \\
\text { fol. } \\
\text { CCXXXVIIIv }\end{array}$ & $\begin{array}{l}\text { Christ with } \\
\text { disciples [R 34], } \\
\text { fol. CLXVIIv }\end{array}$ & $\begin{array}{l}\text { Christ with } \\
\text { disciples [R 35], } \\
\text { fol. CLXXIIIv }\end{array}$ & $\begin{array}{l}\text { Christ with } \\
\text { disciples [H } \\
\text { 1031], fol. } \\
\text { CLXXXI }\end{array}$ \\
\hline \multicolumn{6}{|c|}{ Festival postil } \\
\hline St Andrew & Mt 4: 18-22 & $\begin{array}{l}\text { Calling of St } \\
\text { Peter and St } \\
\text { Andrew [S 57], } \\
\text { fol. II }\end{array}$ & $\begin{array}{l}\text { Calling of St } \\
\text { Peter and St } \\
\text { Andrew [S 57], } \\
\text { fol. II }\end{array}$ & $\begin{array}{l}\text { Calling of St } \\
\text { Peter and St } \\
\text { Andrew [S 57], } \\
\text { fol. II }\end{array}$ & $\begin{array}{l}\text { Christ calming } \\
\text { the storm [H } \\
\text { 1015], fol. II }\end{array}$ \\
\hline St Thomas & J 20: 24-29 & $\begin{array}{l}\text { Incredulity of } \\
\text { Thomas [S 25], } \\
\text { fol. Vv }\end{array}$ & $\begin{array}{l}\text { Incredulity of } \\
\text { Thomas [R 33], } \\
\text { fol. VI }\end{array}$ & $\begin{array}{l}\text { Incredulity of } \\
\text { Thomas [R 33], } \\
\text { fol. VI }\end{array}$ & $\begin{array}{l}\text { Incredulity of } \\
\text { Thomas [H } \\
\text { 1029], fol. VIv }\end{array}$ \\
\hline Christmas Eve & Lk 2: 1-13 & $\begin{array}{l}\text { Nativity of } \\
\text { Christ [S 5], fol. } \\
\text { VIII }\end{array}$ & $\begin{array}{l}\text { Nativity of } \\
\text { Christ [R 5], fol. } \\
\text { IX }\end{array}$ & $\begin{array}{l}\text { Nativity of } \\
\text { Christ [R 5], fol. } \\
\text { IX }\end{array}$ & $\begin{array}{l}\text { Adoration of } \\
\text { the Shepherds } \\
\text { [H 1005], fol. X }\end{array}$ \\
\hline St Stephen & Acts 6: $1-7: 60^{3}$ & $\begin{array}{l}\text { Stoning of St } \\
\text { Stephen [S 58], } \\
\text { fol. XIIv }\end{array}$ & $\begin{array}{l}\text { Stoning of St } \\
\text { Stephen [S 58], } \\
\text { fol. XIV }\end{array}$ & $\begin{array}{l}\text { [empty square } \\
\text { space], fol. XIV }\end{array}$ & $\begin{array}{l}\text { Christ and the } \\
\text { Pharisees and } \\
\text { stoning of a } \\
\text { prophet [H } \\
\text { 1007], fol. XV }\end{array}$ \\
\hline $\begin{array}{l}\text { Massacre of the } \\
\text { Innocents }\end{array}$ & Mt 2: 13-18 & $\begin{array}{l}\text { Massacre of the } \\
\text { innocents [S } \\
\text { 59], fol. XVII }\end{array}$ & $\begin{array}{l}\text { Massacre of the } \\
\text { innocents [S } \\
\text { 59], fol. XX }\end{array}$ & $\begin{array}{l}\text { Massacre of the } \\
\text { innocents [S } \\
\text { 59], fol. XX }\end{array}$ & $\begin{array}{l}\text { Massacre of the } \\
\text { innocents [S } \\
\text { 59], fol. XXI }\end{array}$ \\
\hline Epiphany & Mt 2: 1-12 & $\begin{array}{l}\text { Adoration of } \\
\text { the Magi [S 7], } \\
\text { fol. XXv }\end{array}$ & $\begin{array}{l}\text { Adoration of } \\
\text { the Magi [R 7], } \\
\text { fol. XXIIIv }\end{array}$ & $\begin{array}{l}\text { Adoration of } \\
\text { the Magi [S 7], } \\
\text { fol. XXIIIv }\end{array}$ & $\begin{array}{l}\text { Adoration of } \\
\text { the Magi [H } \\
\text { 1011], fol. } \\
\text { XXIVv }\end{array}$ \\
\hline $\begin{array}{l}\text { Conversion of } \\
\text { St Paul }\end{array}$ & Acts 9: $1-25^{4}$ & $\begin{array}{l}\text { Conversion of } \\
\text { St Paul [S 60], } \\
\text { fol. XXIII }\end{array}$ & $\begin{array}{l}\text { Conversion of } \\
\text { St Paul [S 60], } \\
\text { fol. XXVII }\end{array}$ & $\begin{array}{l}\text { Conversion of } \\
\text { St Paul [S 60], } \\
\text { fol. XXVII }\end{array}$ & $\begin{array}{l}\text { Conversion of } \\
\text { St Paul [S 60], } \\
\text { fol. XXVIII }\end{array}$ \\
\hline St Mathias & Mt 11: 25-30 & $\begin{array}{l}\text { Christ } \\
\text { preaching and } \\
\text { Catholic } \\
\text { hierarchs [S 61], } \\
\text { fol. XXVIv }\end{array}$ & $\begin{array}{l}\text { Christ } \\
\text { preaching and } \\
\text { Catholic } \\
\text { hierarchs, fol. } \\
\text { XXXI }\end{array}$ & $\begin{array}{l}\text { [empty square } \\
\text { space], fol. } \\
\text { XXXI }\end{array}$ & $\begin{array}{l}\text { Christ } \\
\text { preaching [H } \\
\text { 1033], fol. } \\
\text { XXXII }\end{array}$ \\
\hline Annunciation & Lk 1: 26-38 & $\begin{array}{l}\text { Annunciation } \\
\text { [S 62], fol. } \\
\text { XXIXV }\end{array}$ & $\begin{array}{l}\text { Annunciation } \\
\text { [S 62], fol. } \\
\text { XXXIVv }\end{array}$ & $\begin{array}{l}\text { Annunciation } \\
\text { [S 62], fol. } \\
\text { XXXV }\end{array}$ & $\begin{array}{l}\text { Annunciation } \\
\text { [S 62], fol. } \\
\text { XXXVIV }\end{array}$ \\
\hline $\begin{array}{l}\text { St Philipp and } \\
\text { Jacob }\end{array}$ & J 14: 1-14 & $\begin{array}{l}\text { [no illustration], } \\
\text { fol. XXXIV }\end{array}$ & $\begin{array}{l}\text { Two Kingdoms } \\
\text { [S 68], fol. XL }\end{array}$ & $\begin{array}{l}\text { Two Kingdoms } \\
\text { [S 68], fol. XL }\end{array}$ & $\begin{array}{l}\text { Christ with } \\
\text { disciples [H } \\
\text { 1035], fol. XLIv }\end{array}$ \\
\hline
\end{tabular}




\begin{tabular}{|c|c|c|c|c|c|}
\hline Feast & Pericope & Luther $1544 b$ & Luther 1545a & Luther 1548 & Luther 1549 \\
\hline $\begin{array}{l}\text { Nativity of St } \\
\text { John the Baptist }\end{array}$ & Lk 1: 57-80 & $\begin{array}{l}\text { Zechariah at } \\
\text { the altar of } \\
\text { Incense [S 63], } \\
\text { fol. XXXVIII }\end{array}$ & $\begin{array}{l}\text { Zechariah at } \\
\text { the altar of } \\
\text { Incense [S 63], } \\
\text { fol. XLV }\end{array}$ & $\begin{array}{l}\text { Zechariah at } \\
\text { the altar of } \\
\text { Incense [S 63], } \\
\text { fol. XLVv }\end{array}$ & $\begin{array}{l}\text { Circumcision } \\
\text { [of St John the } \\
\text { Baptist] [H } \\
\text { 1010], fol. } \\
\text { XLVIIv }\end{array}$ \\
\hline $\begin{array}{l}\text { Beheading of St } \\
\text { John the Baptist }\end{array}$ & Mt 6: 17-29 & $\begin{array}{l}\text { Beheading of St } \\
\text { John the Baptist } \\
\text { [S 64], fol. } \\
\text { LXV }^{5}\end{array}$ & $\begin{array}{l}\text { Beheading of St } \\
\text { John the Baptist } \\
\text { [S 64], fol. LIv }\end{array}$ & $\begin{array}{l}\text { Beheading of St } \\
\text { John the Baptist } \\
\text { [S 64], fol. LIv }\end{array}$ & $\begin{array}{l}\text { Beheading of St } \\
\text { John the Baptist } \\
\text { [S 69], fol. LIIIv }\end{array}$ \\
\hline $\begin{array}{l}\text { St Peter and } \\
\text { Paul }\end{array}$ & Mt 16: 13-19 & $\begin{array}{l}\text { Adoration of } \\
\text { the Crucifix } \\
\text { and Catholic } \\
\text { hierarchs [S 65], } \\
\text { fol. XLIII }\end{array}$ & $\begin{array}{l}\text { Adoration of } \\
\text { the Crucifix } \\
\text { and Catholic } \\
\text { hierarchs [S 65], } \\
\text { fol. LIVv }\end{array}$ & $\begin{array}{l}\text { Christ with } \\
\text { disciples [R 34], } \\
\text { fol. LV }\end{array}$ & $\begin{array}{l}\text { Christ with } \\
\text { disciples [H } \\
\text { 1031], fol. LVII }\end{array}$ \\
\hline $\begin{array}{l}\text { St Mary } \\
\text { Magdalene }\end{array}$ & Lk 7: 36-50 & $\begin{array}{l}\text { Sinner } \\
\text { anointing } \\
\text { Christ's feet [S } \\
66], \text { fol. XLVII }\end{array}$ & $\begin{array}{l}\text { Sinner } \\
\text { anointing } \\
\text { Christ's feet [S } \\
66], \text { fol. LX }\end{array}$ & $\begin{array}{l}\text { Sinner } \\
\text { anointing } \\
\text { Christ's feet [S } \\
\text { 66], fol. LX }\end{array}$ & $\begin{array}{l}\text { Sinner } \\
\text { anointing } \\
\text { Christ's feet [S } \\
\text { 65], fol. LXII }\end{array}$ \\
\hline $\begin{array}{l}\text { St James the } \\
\text { Elder }\end{array}$ & Mk 10: $35-45^{6}$ & $\begin{array}{l}\text { Christ rebukes } \\
\text { the sons of } \\
\text { Zebedee [S 67], } \\
\text { fol. LI }\end{array}$ & $\begin{array}{l}\text { Christ rebukes } \\
\text { the sons of } \\
\text { Zebedee [S 67], } \\
\text { fol. LXV }\end{array}$ & $\begin{array}{l}\text { Christ rebukes } \\
\text { the sons of } \\
\text { Zebedee [S 67], } \\
\text { fol. LXVv }\end{array}$ & $\begin{array}{l}\text { Christ rebukes } \\
\text { the sons of } \\
\text { Zebedee [S 66], } \\
\text { fol. LXVIIv }\end{array}$ \\
\hline Visitation & Lk 1: 39-56 & $\begin{array}{l}\text { Visitation [S } \\
\text { 68], fol. LIVv }\end{array}$ & $\begin{array}{l}\text { Visitation [S 68], } \\
\text { fol. LXVIIIv }\end{array}$ & $\begin{array}{l}\text { Visitation [S } \\
\text { 68], fol. LXIX }\end{array}$ & $\begin{array}{l}\text { Visitation [S } \\
\text { 67], fol. LXXIv }\end{array}$ \\
\hline $\begin{array}{l}\text { St } \\
\text { Bartholomew }\end{array}$ & Lk 22: $24-30^{7}$ & $\begin{array}{l}\text { Two Kingdoms } \\
\text { [S 69], fol. LXII }\end{array}$ & $\begin{array}{l}\text { Two Kingdoms } \\
\text { [S 69], fol. } \\
\text { LXXVIII }\end{array}$ & $\begin{array}{l}\text { Two Kingdoms } \\
\text { [S 69], fol. } \\
\text { LXXVIIIv }\end{array}$ & $\begin{array}{l}\text { Christ with } \\
\text { disciples [H } \\
\text { 1031], fol. } \\
\text { LXXXv }\end{array}$ \\
\hline St Matthew & Mt 9: 9-13 & $\begin{array}{l}\text { Calling of St } \\
\text { Matthew [S 70], } \\
\text { fol. LXVIIv }\end{array}$ & $\begin{array}{l}\text { Calling of St } \\
\text { Matthew [S 70], } \\
\text { fol. LXXXI }\end{array}$ & $\begin{array}{l}\text { Calling of St } \\
\text { Matthew [S 70], } \\
\text { fol. LXXXIv }\end{array}$ & $\begin{array}{l}\text { Calling of St } \\
\text { Matthew [S 70], } \\
\text { fol. LXXXIV }\end{array}$ \\
\hline \multirow{2}{*}{ St Michael } & Mt 18: 1-10 & $\begin{array}{l}\text { Woman of the } \\
\text { Apocalypse [S } \\
71], \text { fol. LXXII }\end{array}$ & $\begin{array}{l}\text { Woman of the } \\
\text { Apocalypse [S } \\
71] \text {, fol. } \\
\text { LXXXVI }\end{array}$ & $\begin{array}{l}\text { Woman of the } \\
\text { Apocalypse [S } \\
71], \text { fol. } \\
\text { LXXXVIv }\end{array}$ & $\begin{array}{l}\text { Woman of the } \\
\text { Apocalypse [S } \\
71] \text {, fol. } \\
\text { LXXXIX }\end{array}$ \\
\hline & & & & $\begin{array}{l}\text { Become like } \\
\text { little children [S } \\
73], \text { fol. } \\
\text { LXXXIXv }\end{array}$ & $\begin{array}{l}\text { Christ with } \\
\text { disciples [R 35], } \\
\text { fol. XCII }\end{array}$ \\
\hline $\begin{array}{l}\text { St Simon and } \\
\text { Jude }\end{array}$ & J 15: 12-17 & $\begin{array}{l}\text { Siege of the } \\
\text { church [S 72], } \\
\text { fol. LXXVV }\end{array}$ & $\begin{array}{l}\text { Siege of the } \\
\text { church [S 72], } \\
\text { fol. XCII }\end{array}$ & $\begin{array}{l}\text { Christ with } \\
\text { disciples [R 35], } \\
\text { fol. XCII }\end{array}$ & $\begin{array}{l}\text { Christ with } \\
\text { disciples [R 35], } \\
\text { fol. XCIVv }\end{array}$ \\
\hline Wedding & & $\begin{array}{l}\text { [no pericope, } \\
\text { no sermon] }\end{array}$ & $\begin{array}{l}\text { Marriage } \\
\text { ceremony [R } \\
62], \text { fol. CV }\end{array}$ & $\begin{array}{l}\text { Marriage } \\
\text { ceremony [R } \\
62], \text { fol. CV }\end{array}$ & $\begin{array}{l}\text { Marriage at } \\
\text { Cana [H 1013], } \\
\text { fol. CIIIv }\end{array}$ \\
\hline Funeral & & & $\begin{array}{l}\text { Raising of the } \\
\text { son of a widow } \\
\text { in Nain [R 54], } \\
\text { fol. CVIIv }\end{array}$ & $\begin{array}{l}\text { Raising of the } \\
\text { son of a widow } \\
\text { in Nain [R 54], } \\
\text { fol. CVIII }\end{array}$ & $\begin{array}{l}\text { Raising of the } \\
\text { son of a widow } \\
\text { in Nain [R 54], } \\
\text { fol. CXv }\end{array}$ \\
\hline
\end{tabular}

1 In most postils Mt 21: 1-9.

2 In most postils Mt 25: 31-46. 


\section{References}

\section{Primary Sources}

Biblia Das ist: Die gantze heylige Schrifft: Deudsch. 1550. Martin Luther, trans. Nuremberg: vom Berg and Neuber, Available online: http://gateway-bayern.de/VD16+ZV+1483 (accessed on 21 November 2020).

Biblia Das ist: Die gantze heylige Schrifft: Deudsch. 1554. Martin Luther, trans. Nuremberg: vom Berg and Neuber, Available online: http://gateway-bayern.de/VD16+B+2736 (accessed on 21 November 2020).

Biblische Figuren des alten und Newen Testaments. 1560. Frankfurt am Main: Feyerabend, Rasch and Zöpfel, Available online: http://gateway-bayern.de/VD16+S+6973 (accessed on 21 November 2020).

Cordatus, Conrad. 1554. Außlegung der Evangelien. Nuremberg: vom Berg and Neuber, fol. 190v. Available online: http://gateway-bayern.de/VD16+E+4596 (accessed on 21 November 2020).

Dietrich, Veit. 1548. Summaria christlicher lehr, für das junge volck, Was aus eym yeden Sontags Euangelio zu mercken sey. Nuremberg: vom Berg and Neuber, fol. F7v. Available online: http://gateway-bayern.de/VD16+D+1632 (accessed on 21 November 2020).

Dietrich, Veit. 1549. Kinder Postilla Vber die Sontags ond der fürnembsten Fest Euangelia durch das gantze Jar. Nuremberg: vom Berg and Neuber, Available online: http://gateway-bayern.de/VD16+D+1576 (accessed on 21 November 2020).

Dietrich, Veit. 1555. Summaria christlicher lehr, für das junge volck, Was aus eym yeden Sontags Euangelio zu mercken sey. Nuremberg: vom Berg and Neuber, Available online: http://gateway-bayern.de/VD16+ZV+4545 (accessed on 21 November 2020).

Eck, Johannes. 1530-1531. Christenliche außlegung der Euangelienn. Ingolstadt: Apian, vol. 1-3, Available online: http://gateway-bayern.de/VD16+E+282; http://gateway-bayern.de/VD16+E+2823; http://gateway-bayern. de/VD16+E+284. (accessed on 21 November 2020).

Hortulus Animae. Lustgarten der Seelen. 1548. Rhau, Georg, ed. Nuremberg: vom Berg and Neuber, Available online: http://gateway-bayern.de/VD16+R+1686 (accessed on 21 November 2020).

Huberinus, Caspar. 1555. Postilla Teutsch. Vber alle Sontagliche vnd der Fürnembsten Feste Euangelien. Nuremberg: vom Berg and Neuber, Available online: http://gateway-bayern.de/VD16+H+5403 (accessed on 21 November 2020).

Luther, Martin. 1520. An den christlichen Adel deutscher Nation von des christlichen Standes Besserung. In D. Martin Luthers Werke. Kritische Gesamtausgabe. Weimar: Böhlau, vol. 6, p. 407. First published 1520.

Luther, Martin. 1529. Auslegunge der Evangelien, von Ostern bis auffs Advent. Magdeburg: Lotter, Available online: http://gateway-bayern.de/VD16+L+4013 (accessed on 21 November 2020).

Luther, Martin. 1530. Auslegung der Episteln vnd Euangelien. Wittenberg: Lufft/Rhau, Available online: http: //gateway-bayern.de/VD16+L+3958; http://gateway-bayern.de/VD16+L+3986; http://gateway-bayern.de/ VD16+L+4014. (accessed on 21 November 2020).

Luther, Martin. 1532. Vthlegginge der Euangeli. Wittenberg: Weiss, Available online: http://gateway-bayern.de/ VD16+L+4027; http://gateway-bayern.de/VD16+L+4028. (accessed on 21 November 2020).

Luther, Martin. 1544. D. Martin Luthers Werke. Kritische Gesamtausgabe. Weimar: Böhlau, vol. 52.

Luther, Martin. 1544a. Haußpostil. Nuremberg: vom Berg and Neuber, Available online: http://gateway-bayern.de/ VD16+L+4832 (accessed on 21 November 2020).

Luther, Martin. 1544b. Haußpostil. Nuremberg: vom Berg and Neuber, Available online: http://gateway-bayern. de/VD16+L+4833 (accessed on 21 November 2020).

In this edition, the feast of Beheading of St John the Baptist is placed between St Bartholomew's and St Matthew's, in subsequent editions it directly succeeds the feast of Nativity of St John the Baptist.

6 In most postils Mt 20: 20-23.

7 In most postils J 15: 12-16. 
Luther, Martin. 1544c. Auslegung der Episteln und Evangelien. Leipzig: Wolrab, Available online: http://gatewaybayern.de/VD16+L+5605; http://gateway-bayern.de/VD16+L+5607; http://gateway-bayern.de/VD16+L+ 5608; http://gateway-bayern.de/VD16+L+3992. (accessed on 21 November 2020).

Luther, Martin. 1913. Predigt am Sonntag Vocem Jocunditatio. In D. Martin Luthers Werke. Kritische Gesamtausgabe. Weimar: Böhlau, vol. 49, p. 735, Written 1545.

Luther, Martin. 1545a. Haußpostil ... über die Sontags und der fürnembsten Fest Evangelia durch das gantze Jar. Edited by Veit Dietrich. Nuremberg: vom Berg and Neuber, Available online: http://gateway-bayern.de/ VD16+ZV+10044 (accessed on 21 November 2020).

Luther, Martin. 1545b. Simplex Et Pia Evangeliorvm, Qvae Dominicis Diebvs, Et In Praecipvis Festis legi solent, explicatio. Nuremberg: vom Berg and Neuber, Available online: http://gateway-bayern.de/VD16+L+4888 (accessed on 21 November 2020).

Luther, Martin. 1546. Haußpostil ... über die Sontags und der fürnembsten Fest Evangelia durch das gantze Jar. Edited by Veit Dietrich. Nuremberg: vom Berg and Neuber, Available online: http://gateway-bayern.de/VD16+L+4836 (accessed on 21 November 2020).

Luther, Martin. 1547. Haußpostil ... über die Sontags und der fürnembsten Fest Evangelia durch das gantze Jar. Edited by Veit Dietrich. Nuremberg: vom Berg and Neuber, Available online: http://gateway-bayern.de/VD16+ZV+ 10052 (accessed on 21 November 2020).

Luther, Martin. 1548. Haußpostill über die Sonntags- und der fürnembsten Fest-Evangelia. Edited by Veit Dietrich. Nuremberg: vom Berg and Neuber, Available online: http://gateway-bayern.de/VD16+L+4842 (accessed on 21 November 2020).

Luther, Martin. 1549. Haußpostill über die Sonntags- und der fürnembsten Fest-Evangelia. Edited by Veit Dietrich. Nuremberg: vom Berg and Neuber, Available online: http://gateway-bayern.de/VD16+L+4847 (accessed on 21 November 2020).

Luther, Martin. 1553. Haußpostill über die Sonntags- und der fürnembsten Fest-Evangelia. Edited by Veit Dietrich. Nuremberg: vom Berg and Neuber, Available online: http://gateway-bayern.de/VD16+L+4852 (accessed on 21 November 2020).

Luther, Martin. 1554. Haußpostill über die Sonntags- und der fürnembsten Fest-Evangelia. Edited by Veit Dietrich. Nuremberg: vom Berg and Neuber, Available online: http://gateway-bayern.de/VD16+L+4854 (accessed on 21 November 2020).

Luther, Martin. 1555. Haußpostill über die Sonntags- und der fürnembsten Fest-Evangelia. Edited by Veit Dietrich. Nuremberg: vom Berg and Neuber, Available online: http://gateway-bayern.de/VD16+L+4856 (accessed on 21 November 2020).

Luther, Martin. 1560. Kirchen Postilla. Edited by Stephan Roth. Nuremberg: vom Berg and Neuber, Available online: http://gateway-bayern.de/VD16+L+5628; http:/gateway-bayern.de/VD16+L+5629. (accessed on 21 November 2020).

Mathesius, Johannes. 1558. Kurze Auslegung der Sonntags-Evangelien. Nuremberg: vom Berg and Neuber, Available online: http://gateway-bayern.de/VD16+M+1505 (accessed on 21 November 2020).

Melanchthon, Philipp. 1552. Postill. Nuremberg: vom Berg and Neuber, Available online: http://gateway-bayern. de/VD16+E+4595 (accessed on 21 November 2020).

Melanchthon, Philipp. 1555. Postill. Nuremberg: vom Berg and Neuber, Available online: http://gateway-bayern. de/VD16+E+4597 (accessed on 21 November 2020).

Das naw testament nach lawt der Christliche(n) kirchen. 1527. Hieronymus Emser, trans. Dresden: Stöckel, Available online: http://gateway-bayern.de/VD16+B+3474 (accessed on 21 November 2020).

Neue biblische Figuren des Alten un Neuen Testaments. 1565. Frankfurt am Main: Feyerabend, Available online: http://gateway-bayern.de/VD16+B+6068 (accessed on 21 November 2020).

Novi testamenti Iesu Christi historia effigiata. 1551. Frankfurt am Main: Gülfferich, Available online: http: //gateway-bayern.de/VD16+B+2563 (accessed on 21 November 2020).

Nürnberger Ratsverlässe über Kunst und Künstler im Zeitalter der Spätgotik und Renaissance (1449) 1474-1618 (1633). 1904. Hampe, Theodor, ed. Wien: Graeser, vol. 1, First written 1449-1618.

Osiander, Andreas. 1990. Schriften und Briefe. Edited by Gerhard Müller and Gottfried Seebaß. Gütersloh: Mohn, vol. 8, April 1543 bis Ende. Written 1543-1548.

Reformacion der Stat Nüremberg. 1522. Nuremberg: Peypus, Available online: http://gateway-bayern.de/VD16+N+ 2028 (accessed on 21 November 2020). 
Seeger, Martin. 1521a. Dyss hand zwen schwytzer Puren gmacht, fürwar sy hand es wol betracht. Edited by Hans Füssli. Zürich: [Froschauer], Available online: http://gateway-bayern.de/VD16+S+5311 (accessed on 21 November 2020).

Seeger, Martin. 1521b. Das hond zwen schweytzer bauren gemacht, Fürwar sy hond es wol betracht. Edited by Hans Füssli. Augsburg: Ramminger, Available online: http://gateway-bayern.de/VD16+S+5309 (accessed on 21 November 2020).

Spangenberg, Johann. 1554. Außlegung der Epistel vnd Euangelien Von Ostern biß auffs Aduent. Nuremberg: vom Berg and Neuber, Available online: http://gateway-bayern.de/VD16+S+7916 (accessed on 21 November 2020).

Spangenberg, Johann. 1557. Postylla Cžeská. A nebo Waykladowé, na Epistoly a Euangeliá, Nedělnij. Nuremberg: vom Berg and Neuber, Available online: http://gateway-bayern.de/VD16+S+7817 (accessed on 21 November 2020).

Spangenberg, Johann. 1559. Außlegung der Epistel vnd Euangelien auff alle Sontage vnd fürnemsten Fest durchs gantze Jar. Nuremberg: vom Berg and Neuber, Available online: http://gateway-bayern.de/VD16+S+7923 (accessed on 21 November 2020).

Spangenberg, Johann. 1564. Außlegung der Epistel vnd Euangelien auff alle Sontage ond fürnemsten Fest durchs gantze Jar. Nuremberg: vom Berg and Neuber, Available online: http://gateway-bayern.de/VD16+S+7930 (accessed on 21 November 2020).

Teutsch Ewangeli Vnd Epistel. 1516. Hagenau: Anshelm and Albrecht, Available online: http://gateway-bayern.de/ VD16+E+4416 (accessed on 21 November 2020).

Weller, Hieronymus. 1559. Postilla Das ist Christliche kurtze vnd richtige Außlegungen der Sontags Episteln vnd Euangelien. Nuremberg: vom Berg and Neuber, Available online: http://gateway-bayern.de/VD16+W+1785 (accessed on 21 November 2020).

\section{Secondary Sources}

Brady, Thomas A. 1983. Phases and Strategies of the Schmalkaldic League: A Perspective after 450 Years. Archiv für Reformationsgeschichte 74: 171-73. [CrossRef]

Brady, Thomas A. 1995. Protestant Politics: Jacob Sturm (1489-1553) and the German Reformation. Leiden: Brill, pp. 260-62.

Bub, Gustav. 1924. Die Politik des Nürnberger Rates während des Interims. Ph.D. thesis, Friedrich-AlexanderUniversität Erlangen, Erlangen, Germany.

Buck, Lawrence P. 2011. Anatomia Antichristi: Form and content of the papal Antichrist. Sixteenth Century Journal 42: 349-68.

Buck, Lawrence P. 2014. The Roman Monster. An Icon of the Papal Antichrist in Reformation Polemics. Kirksville: Truman State University Press, pp. 94-102.

Burkhardt, Johannes. 2002. Das Reformationsjahrhundert: Deutsche Geschichte zwischen Medienrevolution und Institutionenbildung 1517-1617. Stuttgart: Kohlhammer.

Chojecka, Ewa. 1961. Deutsche Bibelserien in der Holzstocksammlung der Jagellonischen Universität in Krakau. Baden-Baden: Heitz.

Close, Christopher W. 2000. The Negotiated Reformation: Imperial Cities and the Politics of Urban Reform, 1525-1550. Cambridge: Cambridge University Press.

De Hommel-Steenbakkers, Nelly. 2009. Censorship or Self-Protection? Modiications in Apocalypse Illustrations in Sixteenth-Century Bibles Printed in the Low Countries. In Infant Milk or Hardy Nourishment? The Bible for Lay People and Theologians in the Early Modern Period. Edited by Wim François and August den Hollander. Leuven: Peeters, pp. 191-221.

Dingel, Irene, ed. 2010. Reaktionen auf das Augsburger Interim. Göttingen: Vandenhoeck \& Ruprecht.

Dodgson, Campbell. 1909. Holzschnitte zu zwei Nürnberger Andachtsbüchern aus dem Anfange des XVI. Jahrhunderts. Berlin: Bruno Cassirer, pp. 5-7.

Dodgson, Campbell. 1911. Catalogue of Early German and Flemish Woodcuts Preserve in the Department of Prints and Drawings in the British Museum. London: British Museum, vol. 2, p. 298.

Dupuigrenet Desroussilles, François. 2019. Under the Sign of Jonah: The Bible in Early Modern Europe. In Lay Readings of the Bible in Early Modern Europe. Edited by Erminia Ardissino and Élise Boillet. Leiden: Brill, pp. 35-36. 
Frymire, John M. 2010. The Primacy of the Postils. Catholics, Protestants, and the Dissemination of Ideas in Early Modern Germany. Leiden: Brill.

Göttler, Christine. 1984. Das älteste Zwingli-Bildnis? Zwingli als Bilderfinder. Der Titelholzschnitt zur, Beschreibung der göttlichen müly‘. Unsere Kunstdenkmäler. Mitteilungsblatt für die Mitglieder der Gesellschaft für Schweizerische Kunstgeschichte 35: 297-309.

Haberkern, Philip K. 2016. Patron, Saint, and Prophet. Jan Hus in the Bohemian and German Reformations. New York: Oxford University Press.

Hamm, Berndt. 2004. Lazarus Spengler (1479-1534)_Der Nürnberger Ratsschreiber im Spannungsfeld von Humanismus und Reformation, Politik und Glaube. Tübingen: Mohr Siebeck Verlag.

Hirsch, Karl Christian. 1750. Geschichte des Interim zu Nürnberg. Leipzig: Langenheim, pp. 107-11.

Jedin, Hubert. 1949. Geschichte des Konzils von Trient. Der Kampf um das Konzil. Freiburg: Herder, vol. 1, pp. 402-3.

Jurkowlaniec, Grażyna. 2017. Confessional Images? The Luther Bible and Sixteenth-Century Biblical Illustrations in Poland. In The Luther Effect in Eastern Europe: History, Culture, Memory. Edited by Joachim Bahlcke, Beate Störtkuhl and Matthias Weber. Berlin: De Gruyter Oldenbourg, pp. 197-209.

Karant-Nunn, Susan. 1979. Luther's Pastors: The Reformation in the Ernestine Countryside. Philadelphia: American Philosophical Society, p. 29.

Kaufmann, Thomas. 2003. Das Ende der Reformation: Magdeburgs "Herrgotts Kanzlei" (1548-1551/2). Tübingen: Mohr Siebeck.

Kaufmann, Thomas. 2014. An den christlichen Adel deutscher Nation von des christlichen Standes Besserung. Tübingen: Mohr Siebeck.

Knauer, Martin. 2015. Hans and Martin Brosamer. Edited by Hand-Martin Kaulbach. Oudekerk aan den Ijssel: Sound \& Vision Publishers, (The New Hollstein German Engravings, Etchings and Woodcuts, 1500-1700).

Kolb, Robert. 2012. Luther and the Stories of God. Biblical Narratives as a Foundation for Christian Living. Grand Rapids: Baker Academic, p. 176.

Komorowska, Magdalena. 2015. Kształt edytorski postylli polskich XV i XVII wieku—w poszukiwaniu staropolskich konwencji wydawniczych. Terminus 17: 317-65.

Leu, Urs B., and Sandra Weidmann. 2019. Huldrych Zwingli's Private Library. Leiden: Brill, pp. 42-45.

Martin, Peter. 1983. Martin Luther und die Bilder zur Apokalypse. Die Ikonographie der Illustrationen zur Offenbarung des Johannes in der Lutherbibel 1522 bis 1546. Hamburg: Wittig.

Mehlhausen, Joachim, ed. 1970. Das Augsburger Interim: Nach den Reichstagsakten deutsch und lateinisch. Neukirchen: Vluyn.

Milway, Michael. 2000. Forgotten Best-Sellers from the Dawn of the Reformation. In Continuity and Change: The Harvest of Late Medieval and Reformation History. Essays Presented to Heiko A. Oberman on His 70th Birthday. Edited by Robert J. Bast and Andrew C. Gow. Leiden: Brill, pp. 113-42.

Moeller, Bernd. 1993. Klerus und Antiklerikalismus in Luthers Schrift an den Christlichen Adel Deutscher Nation. In Anticlericalism in Late Medieval and Early Modern Europe. Edited by Peter A. Dykema. Leiden: Brill, pp. 353-65.

Pfeiffer, Gerhard. 1986. Die Stellungnahme der Nürnberger Theologen zur Einführung des Interims 1548. In Humanistas-Christianitas Festschrift für Walther von Löwenich. Edited by Karlmann Beyschlag, Gottfried Maron and Eberhard Wölfel. Witten: Luther-Verlag, pp. 111-33.

Ptaszyński, Maciej. 2017. Beruf und Berufung: Die evangelische Geistlichkeit und die Konfessionalisierung in den Herzogtümern Pommern, 1560-1618. Göttingen: Vandenhoeck \& Ruprecht.

Rublack, Hans-Christoph. 1992. Lutherische Predigt und gesellschaftliche Wirklichkeiten. In Die lutherische Konfessionalisierung in Deutschland. Wissenschaftliches Symposion des Vereins für Reformationsgeschichte. Edited by Hans-Christoph Rublack. Gütersloh: Gütersloher Verlagshaus Mohn, pp. 344-99.

Schindling, Anton. 1989. Nürnberg. In Die Territorien des Reichs im Zeitalter der Reformation und Konfessionalisierung: Land und Konfession 1500-1650. Edited by Anton Schindling. Münster: Aschendorff, vol. 1, pp. 31-42.

Schmidt, Georg. 1984. Die Haltung des Städtecorpus zur Reformation und die Nürnberger Bündnispolitik. Archiv für Reformationsgeschichte 75: 194-232. [CrossRef]

Schmidt, Gary D. 1985. A Fell Woman and Full of Strife. The Legend of Hédroit, the Smith's Wife. Mediaevalia 11: 47-61.

Schoch Rainer, Matthias Mende, and Anna Scherbaum. 2004. Albrecht Dürer. Das druckgraphische Werk. Munich: Prestel, vol. 3. 
Schorn-Schütte, Luise, ed. 2005. Das Interim: Herrschaftskrise und Glaubenskonflikt. Gütersloh: Gütersloher Verlagshaus.

Schorn-Schütte, Luise. 2015. Gottes Wort und Menschenherrschaft. Politisch-Theologische Sprachen im Europa der Frühen Neuzeit. Munich: C.H. Beck, pp. 45-117.

Scribner, Robert W. 1994. For the Sake of Simple Folk. Popular Propaganda for the German Reformation. Oxford: Clarendon Press. First published 1981.

Seebaß, Gottfried. 1997. Mittelalterliche Kunstwerke in evangelisch gewordenen Kirchen Nürnbergs. In Die bewahrende Kraft des Luthertums: Mittelalterliche Kunstwerke in evangelischen Kirchen, edited by Johann Michael Fritz. Regensburg: Schnell \& Steiner, pp. 34-53.

Strobel, Georg Theodor. 1772. Nachricht von dem Leben und den Schriften Veit Dietrichs. Altdorf: Schupfel, pp. 128-40.

Stupperich, Martin. 1973. Das Augsburger Interim als apokalyptisches Geschehnis nach Osiander. Archiv für Reformationsgeschichte 64: 225-45. [CrossRef]

Von Friedeburg, Robert. 2002. Civic Humanism and Republican Citizenship in Early Modern Germany. In Republicanism. A Shared European Heritage. Republicanism and Constitutionalism in Early Modern Europe. Edited by Martin van Gelderen and Quentin Skinner. Cambridge: Cambridge University Press, vol. 1, p. 133.

Wandel, Lee Palmer. 2006. The Eucharist in the Reformation. Incarnation and Liturgy. Cambridge: Cambridge University Press, pp. 121-32.

Whitford, David. 2008. The Papal Antichrist: Martin Luther and the Underappreciated Influence of Lorenzo Valla. Renaissance Quarterly 61: 26-52.

Zapalac, Kristin Eldyss Sorensen. 1990. "In His Image and Likeness". Political Iconography and Religious Change in Regensburg, 1500-1600. Ithaca and London: Cornell University Press, pp. 76-78.

Publisher's Note: MDPI stays neutral with regard to jurisdictional claims in published maps and institutional affiliations. 